\title{
III Persecution and Secrets
}

\section{Abulafia: The Art of Writing/Teaching and Persecution}

As is well-known, despite their formal status as part of the primary elite in their respective religions, both Maimonides and Averroes were sharply criticised in their lifetimes due to their philosophical views although they were masters of esoteric writing. Averroes was even persecuted towards the end of his life. They were very cautious in formulating their writings because they did not wish to agitate the populace or provoke antagonism and because they occupied high positions in their respective courts. The critiques addressed to them have much to do with the introduction of a stark dichotomy within their religious discourse between the plain sense and the hidden secrets of sacred scriptures. The hidden secrets were philosophical in nature, but were sometimes conceived as being hinted at in the interpreted texts. This dichotomy corresponds to another dichotomy on the anthropological plane between the masses and the elite. ${ }^{1}$

These anthropological dichotomies correspond to the two types of discourse or narratives: one religious, mythical, national, and historical (that is, the exoteric dimension of their writings) and the other Neo-Aristotelian, abstract, and individualistic (esoteric). In a way, the two levels of discussion contradict each other, though this point was rarely put into relief by the two philosophers as part of the religious responsibility they enjoyed as legalistic figures. In fact, both Maimonides and Averroes referred to the role played by a third category, the Rabbis and the Mutakallimun, whom they believed were spreading erroneous theological views among the multitude, a view that was later adopted by Abulafia, who was critical of certain Rabbis, as we shall see in chapter 9 below. The social and intellectual positions of Maimonides and Averroes produced similar approaches; in addition, Maimonides's later thought was influenced by some of Averroes's writings. ${ }^{2}$

Abulafia, on the other hand, did not occupy a formal position in Jewish society: he was not part of the primary elite, he did not serve as the Rabbi of a community, and he did not become a legalistic figure. As he himself confesses, his Rabbinic back-

\footnotetext{
1 See Klein-Braslavy, King Solomon and Philosophical Esotericism and Halbertal, Concealment and Revelation, 49.

2 See Warren Zev Harvey, "Averroes and Maimonides on the Duty of Philosophical Contemplation (I'tibār)" [Hebrew], Tarbiz 58 (1989): 75-83. See also David Gonzalo Maeso, “Averroes (1126-1198) y Maimonides (1135-1204), dos glorias de Córdoba,” Miscelánea de Estudios Árabes y Hebraicos 1617, no. 2 (1967/68): 139-64; Ralph Lerner, "Le philosophe comme législateur: Maïmonide et Averroès," Critique 728-729 (2008): 8-27; Steven Harvey, "Arabic into Hebrew: The Hebrew Translation Movement and the Influence of Averroes upon Medieval Jewish Thought," in The Cambridge Companion to Medieval Jewish Philosophy, eds. Daniel H. Frank and Oliver Leaman (Cambridge: Cambridge University Press, 2003): 250-80; and Daniel J. Lasker, "Averroistic Trends in Jewish-Christian Polemics in the Late Middle Ages,” Speculum 55 (1980): 294-304.
} 
ground was relatively poor, for which reason he may be seen as belonging to what I propose to call the secondary elite. ${ }^{3}$ As seen above, he was a rather itinerant scholar who did not stay in the same town for long periods, with the exception of few consecutive years in Messina in Sicily, whence he also visited Palermo and likely the island of Comino.

However, Abulafia's vision of man followed Aristotle, as he conceived man to be a social being by nature. ${ }^{4}$ This dependence on society increased Abulafia's need to resort to cautious language and esotericism. However, despite this dependence, his attitude to both the multitude, including Jews, and even to contemporary Rabbis is quite disdainful-much more so than what may be found in the attitude to the vulgus in Plato, Averroes, or Maimonides, as we shall see in the next chapter. ${ }^{5}$ In any case, his more open attitude towards revelation and law, which is in a manner more reminiscent of the Latin radical Averroists, is much more problematic. His attitude towards the sacred text and its esoteric message is even more problematic, especially given the assumption that he saw himself as a prophet who was receiving messages from above and believed that the time of redemption was at hand; that is, he believed that he was a Messiah.

A characteristic of Abulafia's later life that is unlike what we know about all the other thirteenth-century Kabbalists is that he was not just an itinerant figure: he was also persecuted and was ultimately banned. For example, he was arrested in the city of Trani (or Terni) around 1279 because of denunciations from Jews and escaped, as he claims, by means of a miracle. ${ }^{6}$ Later on, he was likely expelled to the small island of Comino, near Malta. ${ }^{7}$ Sometime in the second half of the 1280s, he entered into a vicious polemic with Rabbi Solomon ibn Adret that culminated in him receiving a banishment from this legalistic figure, a ban that was effective in the Iberian Penin-

3 For the distinction between the primary and secondary elites in Kabbalah and the reverberation of this distinction on the nature of their respective forms of Kabbalah, see my "The Kabbalah's 'Window of Opportunities." For ecstatic Kabbalah, see my "Maimonides's Guide of the Perplexed and the Kabbalah,” 216-18.

4 Mafteah ha-Hokhmot, 60:

כי האדם מדיני בטבע ולא יחיה אדם לבדו כי אם ימים מעטים ובמקרה שיזדמן לו מזונו הטבעי ההכרחי לצורך חייו.

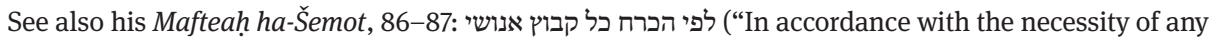
human collective").

5 See Erwin I. J. Rosenthal, “The Place of Politics in the Philosophy of ibn Rushd,” BOAS 15, no. 2 (1953): 246-78.

6 Commentary on Sefer ha-'Edut, printed in Mașref ha-Śekhel, 57:

ובלכתו עבר דרך טראני ונתפש בידי גוים מפני מלשינות שהלשינוהו יהודים ונעשה לו נס ועזרו השם וניצל.

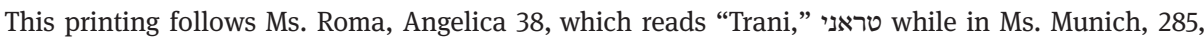
which is a later codex, it is spelt טרני. See Sermoneta's decoding of the name of the town as Terni, a town in Umbria in central Italy that was part of the Papal States, in "Hillel ben Samuel ben Eleazer of Verona," 53, note 51, which probably follows the Angelica manuscript. It is difficult to determine the location of the place where Abulafia was imprisoned since there were Jewish communities in both towns in the medieval period.

7 See Sefer ha-Ot, 79. 
sula until the Jews' expulsion from Spain. ${ }^{8}$ We may well assume that those events were related not only to the specific content of his writings and teachings, but also to his boasting of being both a prophet and a Messiah. This may also be the reason for the problems that occurred in Capua in 1279 and his short imprisonment by the Minorite brothers in Rome after his unsuccessful attempt to meet the pope in the small town where his family had a palace sometime in the later part of 1280 . This palace, known as Castro Firmano, still exists today: it can be found north of Rome in Soriano nel Cimino.

However, even earlier than these events, if my dating of a certain passage in his writing is correct, ${ }^{9}$ he felt himself persecuted for different reasons:

Behold, the good is discerned by [means of] evil and evil is discerned by good, and all this is interpreted in Sefer Yeșirah..$^{10}$ On this issue, the power of my fear was overcome, and I compelled my will and I sent my hand to [deal with] ${ }^{11}$ what is somewhat higher than my capacity; seeing as I did that, my generation is calling me a heretic and an Epicurean ${ }^{12}$ because I worshipped God in truth and not according to the fantasy of the nation ${ }^{13}$ that walks in darkness, since they and those like them were immersed in the abyss [and] were glad, and they were [also] glad to cause my immersion in their vanities and also in the darkness of their deeds. ${ }^{14}$

8 See my "The Rashba and Abraham Abulafia: The History of a Neglected Kabbalistic Polemic" [Hebrew], in 'Ațara le-Haim: Studies in Talmudic and Rabbinic Literature in Honor of Professor Haim Zalman Dimitrovsky, ed. Daniel Boyarin (Jerusalem: Magnes Press, 2000): 235-51.

9 See Idel, "Abraham Abulafia's Works and Doctrine," 10.

10 Cf. 6:5. See also Shlomo Pines, "Truth and Falsehood versus Good and Evil: A Study of Jewish and General Philosophy in Connection with the Guide of the Perplexed, I,2," in Studies in Maimonides, 124-25, note 88 .

11 This is a Hebrew idiom which means "I dared."

12 This is a Rabbinic term for heresy. For the antonomastic use of this term in Rabbinic literature, see Ephraim E. Urbach, The Sages: Their Concepts and Beliefs, trans. Israel Abrahams, 2nd rev. ed. (Jerusalem: Magnes Press, 1979), 1:29, 354, 652. For the more general view of philosophers as heretical in the Jewish Middle Ages, see Hannah Kasher, “'The Philosophers Never Believed in Anything' (Rabbi Isaac Arama): Notes on the Accusation That Philosophers are Heretics in Medieval Jewish Philosophers" [Hebrew], in Jewish Thought and Jewish Belief, ed. Daniel J. Lasker (Beer-Sheva: Ben-Gurion University Press, 2012): 57-70.

13 Though the term ha-'am can be also translated as "populace," as it is in Maimonides's Guide of the Perplexed, 3:54, Pines, 638, following Isaiah 9:1, I prefer to use the word "nation" here. There is no good reason to doubt that he is here referring to the Jews who persecuted Abulafia.

14 Ms. Jerusalem, NUL, $8^{0}$ 1303, fol. 73a, printed with several errors in Cohen's edition of Sefer Ge'ulah, 5-6:

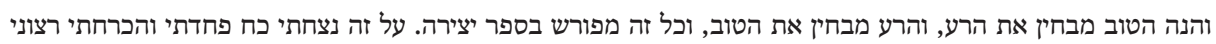

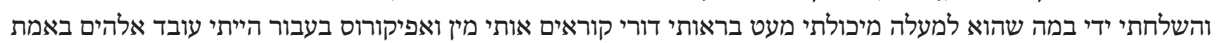

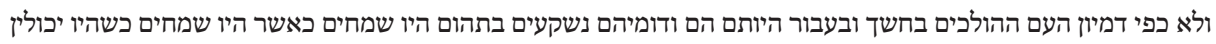
להשקיעני גם אני בהבליהם ובמחשך מעשיהם. See also Scholem, Major Trends in Jewish Mysticism, 129-30, 380, note 40, and Idel, "Sefer Yetzirah and Its Commentaries,” 530. 
This early testimony of the strong critiques that the ecstatic Kabbalist presumably encountered, likely in Catalonia, should be examined in any serious consideration of his thought before a harmonistic picture of Abulafia as part of the more general approach in Kabbalah as a whole is offered. No other Kabbalist testifies so clearly that he was accused of heresy, and such an accusation is grounded, in my opinion, in Abulafia's affinity with Maimonides.

Moreover, in the very same book, Abulafia claims that if Maimonides had explained the commandments in accordance with philosophical spirituality, he too would now be considered "heretical and Epicurean" by the Jews. ${ }^{15}$ Thus, at least according to this early text, his concern was not with what Christians or other religious persons would say, but with what Jews thought about his teachings. From this point of view, Abulafia's approach to the nature of worship is as subversive as his approach to the Hebrew language, and, as we shall see, his approach to the status of the Torah. The critique of the genetic vision of the nation, as well as the perfection of the Hebrew language, Torah, commandments, and Temple, esoteric as it may be, is part of Abulafia's Maimonidean naturalism. ${ }^{16}$

However, what seems important to me is the claim Abulafia makes in the same context: had Maimonides interpreted the commandments according to the various methods of the prophetic Kabbalah, those who condemned him as a heretic would certainly have been correct. ${ }^{17}$ This is indeed a keen recognition of the transgressive nature of Abulafia's own interpretations of the commandments, at least as he expected they would be understood by some other traditional Jews, a topic that deserves a more detailed elaboration that cannot be offered within this framework.

Abulafia's explicit testimony of having been accused of heresy also fits another, somewhat more veiled testimony found in a book written in 1282 in Messina: his Commentary on Sefer ha-Meliṣ. In this text, Abulafia describes the following situation:

15 Sefer Ge'ulah, 14-15. I have already corrected the reading of this text in my study "Sefer Yetzirah and Its Commentaries," 530-31, where I printed the improved Hebrew passage. This text should be compared to the much later (though equally important) discussion found in Imrei Šefer, 20-21, where he claims that Maimonides wrote only the "plain" sense of the commandments, while the secret meanings of the commandments are interpreted as referring to Hokhmah and Binah ("love" and "understanding") and Limmud ("study"). See also chapter 10 note 182 below. Let me point out that Maimonides and Averroes influenced Abulafia's understanding of the emergence of the ideal of mystical union without an accompanying antinomianism, as was the case of the extreme mysticism in some Christian circles in Central Europe known as the "Free Spirit." See Robert E. Lerner, The Heresy of the Free Spirit in the Later Middle Ages (Notre Dame: Notre Dame University Press, 1972), 61-68. 16 Needless to say, the sources of the propensity to naturalist explanations are found in Greek philosophy and it was mediated by Muslim texts. See, e. g., Majid Fakhry, A History of Islamic Philosophy (New York: Columbia University Press, 1970), 112-24. See also note 370.

17 Sefer Ge'ulah, 14-15. 
Nowadays, because of our being in this lengthy exile that we are in [...] this name ${ }^{18}$ was hidden from the sages who are members of our nation, $a$ fortiori from their multitude, ${ }^{19}$ so that anyone who searches for the knowledge of this name or other holy names similar to it becomes a heretic and an Epicurean to the sages of this generation. ${ }^{20}$

In my opinion, it is difficult to miss the precise identity of the person in that generation who was seeking to know the various divine names and was consequently called a heretic and an Epicurean: in my opinion, it was Abulafia himself, who regarded the disclosure of the unknown divine name ' $H W Y$ as the peak of his revelatory achievements. I wonder whether some kind of skandalon two years earlier in Capua was the backdrop for this diagnosis.

This awareness of the danger of being considered a heretic is also found in Sefer Or ha-Śekhel, a book whose content will be the subject of many of our discussions below. In a passage that may reflect some form of autobiographical experience, he writes:

When someone wishes to disclose the true faith to an illuminate, ${ }^{21}$ he [the teacher] shall comprehend whether his [the latter's] mind bears it or not. And this is the sign: if he rejoices in it and is afraid of hearing its secret ${ }^{22}$ and does not break its fences, ${ }^{23}$ which are to it as the keys to the lock, by means of which he prevents the garden from being entered by evil beasts, you should immediately understand that he received the intellectual faith and that he is a wise person, who understands by himself ${ }^{24}$ [...]. But if you reveal a secret to him and he is worried and astonished about it and thinks that all his faith will be removed because of it, ${ }^{25}$ and [he thinks that] you are a fool or a heretic and an Epicurean, do not nourish him with the potion of life, lest you kill him. $^{26}$

18 Namely, the divine name.

19 The plural form מהמוניהם is not so clear.

20 Sefer ha-Melis, printed in Mașref ha-Śekhel, 36:

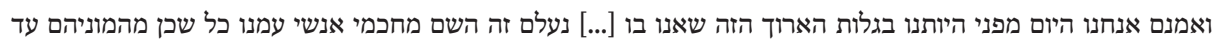
ששב היום אצל חכמי דורנו זה, כל המבקש שום ידיעה בשם כזה אות או בזולתו מן השמות הקדושים הדומים לו כמין מלמין עמד

ואפיקורוס.

See also Gan Na'ul, 40, and Scholem, Major Trends in Jewish Mysticism, 383, note 92, where he acknowledges that he was accused of believing in the pre-eternity of the world, like Aristotle. Compare to Oșar 'Eden Ganuz, 2:1, 212, and Sitrei Torah, 91-92. See also Joseph Dan, Kabbalists in Spain in the Thirteenth Century [Hebrew], vol. 9, History of Jewish Mysticism and Esotericism (Jerusalem: Shazar Center, 2013), 409, who claims that Abulafia believed in pre-eternity, this being the reason why language did not play a role in the creation of the world.

21 Who is still an aspirant.

22 That is, the secret of the true faith.

23 This is a theme for keeping a certain social framework that recurs throughout this book.

24 This is a phrase found in Rabbinic literature describing the part that is apt to deal with esoteric topics. See Mishnah Hagigah, 2:1.

25 Compare the description of Rabbi Nathan, Abulafia's student, to whom Or ha-Śekhel was dedicated. His faith was prone to be shaken by his study of philosophy. See Le Porte della Giustizia, 477. 26 Or ha-Śekhel, 10: 
These accusations of heresy are found in several of Abulafia's writings and may have been one of the main causes of his persecutions. The manner in which he envisioned these persecutions is quite revealing: in his opinion, they proved that he was indeed a prophet because suffering and persecutions were also the fate of the biblical prophets. ${ }^{27}$ Abulafia coupled this "protestant" prophetic attitude found in ancient Judaism with a philosophical attitude towards reforming Judaism by means of a series of mentalistic interpretations that accompanied his self-perception as a Messiah.

The warning about the potential lethal danger stemming from the revelation of secrets is quite extraordinary in the entire history of Jewish esotericism, and it shows that persecution is also to be understood not only as the consequence of writing, but also as the consequence of the oral divulgence of secrets to people who are not appropriate audiences. If we accept Abulafia's claims of persecution, then his testimony is exceptional because no other thirteenth-century Kabbalist gave a similar testimony. ${ }^{28}$

The sharp tension between the plain and the esoteric senses of the Hebrew Bible, to the extent that in some cases the latter is conceived as contradicting or deconstructing the former, is, according to some of Abulafia's views, quite obvious. ${ }^{29}$ In one text, Abulafia writes: "Those are secrets of the Torah that are truthful for the sages, but indeed according to the fools, they contradict the Torah." ${ }^{30}$ This is a guarded esotericism: it prevents the unqualified from reaching topics that they cannot un-

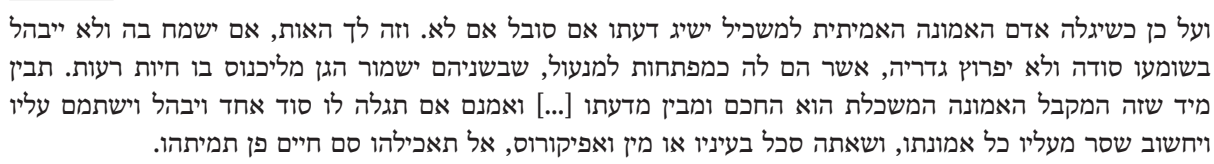
See also the warning not to be surprised or astonished by the content of his book, Or ha-Śekhel, 69. Compare this to Abulafia's resort to the possibility of being accused of minut, heresy, in his early treatise Mafteah ha-Ra'ayon, 25. On the accusation of heresy and Epicureanism addressed to a person studying Greek philosophy, see his Sitrei Torah, 35. On the lethal danger related to disclosing secrets to the masses, see Amir-Moessi, The Divine Guide in Early Shi'ism, 129.

27 See Sefer Ge'ulah, 5.

28 We should distinguish between critiques of ideas, found in many writings concerning Kabbalah or philosophy, and actual personal persecutions, which, as far as we know as far as the medieval scene was concerned, were quite rare in Judaism.

29 See my "On the Secrets of the Torah in Abraham Abulafia," 403-9, and see also Wolfson, Abraham Abulafia, 175.

30 Hayyei ha-Nefeš, 13: סתרי תורה הם באמת לחכמים, וסותרי תורה לפתאים בלא ספק. See also Or ha-Śekhel, 9. For the use of the word "fool" in the Guide and some later echoes, see Harvey, Falaquera's "Epistle of the Debate," 15-16, note 5, and Schwartz, "Magic, Philosophy and Kabbalah," 104. See also the stark distinction between the two extremities: the multitude is concerned solely with the plain sense, and the special individual is concerned only with the hidden sense, as described in Or haSekhel, 39-40. This is the background of Abulafia's statement in Sitrei Torah, 118, discussed by Wolfson, Language, Eros, Being, 27, 423, note 257, and in Abraham Abulafia, 81-88. In the latter text, he interprets the statement differently, in a manner that fits the sixteenth-century Rabbi Moses Cordovero's quite different vision of secrets, as what was earlier called an essential issue. For Abulafia, it is an anthropological and cognitive issue. See also Appendix E note 219 below. 
derstand and allows qualified recipients to learn them. On the surface of the text, this esotericism does not seem like a mysterious issue that is veiled in a cloud of unknowing in order to prevent transmission. Rather, it works with the basic problem of the inferior nature of the minds of some of the possible audience, who nevertheless need instruction. The ineffability of the divine, let me emphasise, is not at stake, but rather the weakness of the human constitution.

This is also the gist of a discussion that I am very much inclined to attribute to Abulafia, which is found anonymously in a manuscript that contains other Abulafian material. After offering some calculations that aim to demonstrate that the concept of ex nihilo can be deduced from the numerical values of the letters of the Tetragrammaton, the Kabbalist writes:

Behold, I have already announced to you this great, wondrous, covered secret, ${ }^{31}$ that is appropriate to hide from someone that is not worthy of it, and he is preoccupied with its knowledge for reasons other than the glory of God, blessed be He, and it is appropriate to reveal it and to speak about it in the entire world in order to hallow it, to honour it for the sake of the glory of God, blessed be He, and this is the reason why I wrote it in a slightly confused manner, intentionally, and because of the will that the possessor of the eyes of the intellect will look at it and the possessor of the eyes of the fool ${ }^{32}$ will not contemplate it. ${ }^{33}$

31 See Abulafia's resort to the very same phrase (הסוד המופלא המכוסה) in his Sitrei Torah, 186. He only resorted to series of adjectives that qualify the secret as extraordinary in a little more than a dozen cases, which is quite a small amount in comparison to the thousands of occurrences of the terms sod or seter without those qualifications. This is one of the reasons why I identify the anonymous passage as having been written by Abulafia.

32 The pun on the Hebrew שכל/סכל is found in many of Abulafia's texts. For example, see Sitrei Torah, 14. Let me present an anonymous passage found in a manuscript that claims that the plain sense is intended for fools:

דע שיש לחכמים דברים נעלמים רמזים במדרשים ובהגדות חתומים ואם נגליהם לעיני הסכלים בדברים בטילים ליודעים חן ולמבינים שכלים.

"You should know that what the sages have are hidden things and hints in the Midrashim, and sealed in the legends, and if in their plain sense [they seem] to be trivial in the eyes of the fools, for those who know the hidden wisdom and those who understand, [they] are intellectual." See Ms. London, British Library 1087, Or. Add. 27173, fol. 64a. The formulation at the end is a little ambiguous. The style is quite reminiscent of Abulafia and its authorship requires further analysis. Compare this view to Levi ben Abraham's statement in Liwyat Hen: The Quality of Prophecy and the Secrets of the Torah, ed. Kreisel, 212:

כי ההכרח הביא להסתיר קצת דברים ולתקן להם משל כדי ללבב שכל הנבונים ולעור עין הכסילים לא יבינום. "Since it was necessary to hide some things, and to prepare for them a parable, in order to arouse the intellect of the wise, but to blind the eyes of the blind, [so that they] will not understand them." 33 Ms. Jerusalem, NUL $8^{0} 1303$, fols. 50b-51a:

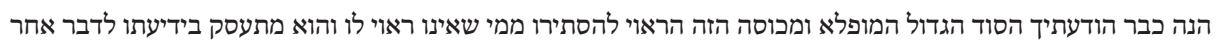

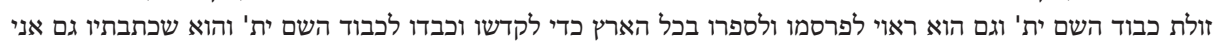

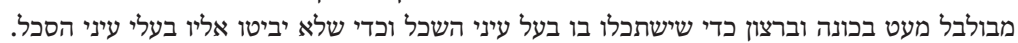

For the affinities between part of the material found in this manuscript and Abulafia's early views, see my "Abraham Abulafia's Works and Doctrine," 30, and especially my Language, Torah, and Hermeneutics, 138 , note 20 , where fol. 52a of this manuscript is mentioned. 
The remark about the intentionally distorted manner of writing the secret is, from a Straussian point of view, paramount, especially since it explicitly conveys Abulafia's consciousness of the need to keep the secret from the vulgus. If this text is to be believed to reflect an actual practice, then there are formulations in Abulafia's writings that are intentionally cast in a confusing manner, a practice that contradicts what he wrote elsewhere about his refusal to take into consideration the dangers involved in disclosing an important secret. ${ }^{34}$

I assume that Abulafia wrote this anonymous passage very early in his career and that the more audacious position was formulated later. In any case, we should note the existence of different, even contradictory positions in his writings concerning the politics of esotericism. In my opinion, this difference was a result of a more general development in his thought, perhaps part of personal experiences of persecution, a development that we shall survey in some detail at the end of Appendix D. ${ }^{35}$

However, in another anonymous and quite provocative statement found in a short treatise for which I also propose Abulafian authorship, we read: "The curse of the plain [sense] is the blessing of the hidden one, and the curse of the hidden [meaning] is the blessing of the plain [sense]." 36 For the time being, this is the most extreme formulation of antagonism towards the plain sense found in Abulafia's writings, and, to the best of my knowledge, in Jewish literature in general. ${ }^{37}$ It is in this general context that Abulafia uses a pun on the name of a philosopher who would say that the "plain senses [pešațim] are said [intended] for the fools

34 See below the passage from Oșar 'Eden Ganuz, 1:2, 51.

35 See below, 345-59.

36 See Ms. Oxford, Bodleian 2047, fol. 69a, and Idel, Kabbalah: New Perspectives, 207-8, 377-78, note 25: וקללת הנגלה הוא ברכת הנסתר, וקללת הנסתר הוא ברכת הנגלה, and I hope to return to this fascinating passage in a separate study on thirteenth-century Kabbalistic hermeneutics. In the context of this passage, it is clear that nigleh and nistar also stand for the second person and the third person, but this is done in the context of an interpretation of the names of the biblical forefathers according to the methods of combining their letters. See also Idel, Absorbing Perfections, 346-47. For another quotation from this text, see chapter 10 below. For the view that the secret sense is the essence and the plain sense is inconsequential [țafel], which he attributes to Maimonides, see Hayyei haNefeš, 12:

העניין המובן מן הנסתר עיקר ונשאר א"כ זולתו טפל כנגדו והנה הורנו כי אין תכלית הכוונה האחרונה בעבור המובן

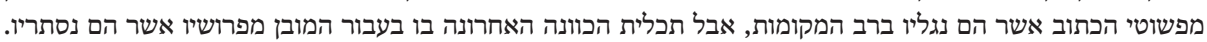
"What is understood from the hidden sense is essential, and what remains in addition to it is inconsequential in comparison to it. And behold, we have been taught that the ultimate intention is not what is understood from the plain sense of the scripture, which is the revealed one in most places, but the ultimate intention is what is understood from the interpretations that are its hidden senses." See also the longer quote from the same book below, 15, quoted below chapter 8 note 59, where the term tafel occurs in a similar context. Indubitably, this is a radicalisation of Maimonides's thought and constitutes an attitude that is the inverse position to that of Spinoza.

37 Compare to Alan de Lille's twelfth-century Latin text, discussed in Marie-Dominique Chenu, $\mathrm{Na}$ ture, Man, and Society in the Twelve Century, eds. and trans. Jerome Taylor and Lester K. Little (Chicago: Chicago University Press, 1968), 99-100. 
[tippšim]." 38 In the Hebrew spelling, the two words in parentheses are compounded from the same consonants, though permutated in a different order. This is not just a repudiation of the plain sense as given in a more gentle or veiled way by other Maimonideans, but a full-fledged rejection of its intellectual relevance. ${ }^{39}$

This approach seems to be the source of Sefer Toledot Adam, a later, anonymously authored treatise likely written under the influence of Abulafia's writings in Italy in the first decades of the fifteenth century:

\begin{abstract}
All speeches and exchanges of [the order of] letters are conventional, [stemming] from the imagination, but the intellect and prophecy do not by themselves need speech and the language of the languages for their comprehension, as the imagination needs. And the speech of the sages is a parable and an enigma and brief talk, though [nevertheless possessing] plenty of meanings, but prophecy does not need even brief talk. However, given that the sage cannot explain the speculation of his wisdom to the masses, since they do not understand his special language, and they did not convene with him [...], this is the reason why you may see sages always laughing in their heart at the fools when they speak their language, which they learned from their early youth. ${ }^{40}$
\end{abstract}

Perhaps in the anonymous author's passage we have a radicalisation of Abulafia's thought that might also have been impacted by the Averroistic sources that he knew, such as the books of the Maimonidean Rabbi Moses Narboni. ${ }^{41}$ In any case, this is an elitist approach that assumes a high, perhaps insurmountable barrier between the elite and the masses. I call this type of approach to the various senses of the biblical text "disjunctive," which means that it operates with the imperative of preventing the vulgus from learning the esoteric interpretations of the Bible. ${ }^{42}$ Again, quite a dramatic shift in comparison to the early Kabbalistic sources and the Ashkenazi approaches with which Abulafia was acquainted. Though dealing

38 Mafteah ha-Hokhmot, 44: וזה שהפילוסוף יעיין בפשטים ויכיר שהם דברים נאמרים לטפשים להכים lier Mafteah ha-Ra'ayon, 69: הנסתר מהכסילים הוא אשר נגלה לחכמים. Let me point out that there is nothing paradoxical here, or in similar statements Abulafia makes, since the secret is conceived as something that transcends the understanding of a certain level of the populace while it is understood by another level. His esotericism is therefore intended to ensure that ignoramuses would not be harmed by the text on the one hand and that the elite would not be harmed by the multitude on the other. 39 See Marc Saperstein, Decoding the Rabbis: A Thirteenth-Century Commentary on the Aggadah (Cambridge, MA: Harvard University Press, 1980), 35-46.

40 Sefer Toledot Adam, Ms. Oxford, Bodleian 836, fol. 169a, translated, with some changes, in Idel, Language, Torah, and Hermeneutics, 144, note 55. The Hebrew original of this text was printed in the Hebrew version of my book on page 136, note 54. For some affinities between this treatise and Abulafia's thought, see Language, Torah, and Hermeneutics, 46; 58; 65; 136; 144, note 55; 179; 181. See also Idel, Messianic Mystics, 352, note 50, and Idel, Kabbalah in Italy, 150-52; 182; 391, note 63. I hope to return to a more sustained analysis of this neglected treatise in a separate study.

41 For Averroes on the nature of prophecy, see Sefer Toledot Adam, fol. 157b.

42 Introduction to Mafteah ha-Hokhmot, 6-7. On the affinity between esotericism and elitism in Maimonides, see Kellner, Maimonides' Confrontation with Mysticism, 16 and note 41. 
with the secrets of the Torah, these other approaches were nevertheless much more "conjunctive."

With Abulafia, however, the tension between the different interpretations and audiences is quite obvious, as we shall see immediately below. In one of the densest passages that deals with the three Rabbinic forms of esotericism, he writes:

At the very beginning of the formation [of man], three types of sins were comprised: idolatry, incest, and shedding blood [homicide]. ${ }^{43}$ And also in the case of circumcision, these three [are found], ${ }^{44}$ since from this, there is the beginning of the creation of the species and its eternal persistence. And this is so in order to change what has been created in accordance with the ultimate divine intention, and this is the first natural intention. The natural intention, which is the account of creation, is to always preserve the human species and to preserve its individuals for a period of time by means of sexual intercourse, while the divine intention, which is the account of the chariot, is to always preserve the distinguished individuals ${ }^{45}$ by means of the revelation of secrets, ${ }^{46}$ which are like the disclosure of the sexual organs in the eyes of the multitude of the species ${ }^{47}$ and matters that are pernicious to be spoken and forbidden to be heard, like things about incest, despite the fact that they are the principles and the others are negligible. And this is the reason why it is incumbent on the multitude belonging to the species to believe the scriptures according to their plain sense, and [subsequently] no secret matter should be revealed to them, since for them, it is shameful, and it is incumbent on the [elite] individuals to believe the inverse, that is, to reveal to themselves the shamefulness of the plain sense and cover it from the others and take the secret sense as fine flour and leave the plain sense as refuse, as it is said "stolen waters are sweet and bread [eaten] in secret is pleasant"; ${ }^{48}$ namely, the secrets of the Torah, which are secrets that are transmitted in a whisper ${ }^{49}$ and intended for the intellect through plenty of thought, and they are stolen and covered from the multitude, and all are hidden, attesting to the two urges, ${ }^{50}$ and according to the plain sense they are one of the command-

43 Those are three cardinal sins in Rabbinic Judaism. The intention here is that those sins are implicitly or explicitly mentioned in the first chapters of Genesis, as the Rabbis understand it. 44 See also Sitrei Torah, 70.

45 Namely, the elite. For more on this issue, see chapter 21 below. On nature being concerned with species rather than individuals, see Goethe's Metamorphosis of Plants, as discussed by Erich Neumann, The Origin and History of Consciousness, trans. Richard Francis Carrington Hull (New York: Harper, 1962), 2:333-34.

46 The secrets are seen as the means of reaching immortality.

47 The term "species" most likely has two different meanings in this context: the human species and the multitude, who are considered heretical because of their incorrect beliefs. See also later in the translated passage, as well as in his Oșar 'Eden Ganuz, 1:1, 21, and Hayyei ha-Nefeš, 9, 10. The category of the human species is very important in Abulafia's anthropology, as we shall see below. It comprises fools and wise men, Jews and non-Jews, all together.

48 Proverbs 9:17.

49 On the topic of transmission in a whisper, see Idel, "In a Whisper." See also Elliot R. Wolfson, "Murmuring Secrets: Eroticism and Esotericism in Medieval Kabbalah," in Hidden Intercourse: Eros and Sexuality in Western Esotericism, eds. Wouter. J. Hanegraaff and Jeffrey J. Kripal (Leiden: Brill, 2008): 65-109.

50 In most of the occurrences of the discussions of the two urges within Rabbinic literature in Abulafia's writings, he refers to the faculties of imagination and intellect. 
ments, which are [needed] for the perfection of the body and the perfection of the soul, ${ }^{51}$ which are necessary or useful..$^{52}$ Behold, the plain sense is the key ${ }^{53}$ for the opening of the gates of the hidden, ${ }^{54}$ and behold, it is part of the category of the hidden by genus but not by species, since the perfection of the body is a preparation for the perfection of the soul, and the perfection of the soul is a preparation for the ultimate felicity, ${ }^{55}$ which is the aim of the ultimate divine intention, which [consists] in the comprehension ${ }^{56}$ of God. ${ }^{57}$

51 The concepts of these two perfections or amendments can be found in Maimonides's Guide of the Perplexed, 3:27, Pines 2:511. For analyses of these concepts, see Miriam Glaston, "The Purpose of the Law according to Maimonides," JQR 67 (1978): 27-51; Warren Zev Harvey, "Maimonides on Human Perfection, Awe, and Politics," in The Thought of Moses Maimonides: Philosophical and Legal Studies, eds. Ira Robinson, Lawrence Kaplan, and Julien Bauer (Lewiston, NY: Edwin Mellen Press, 1990): 1-15; Alexander Altmann, “Maimonides’s Four Perfections," Israel Oriental Studies 2 (1972): 15-24; and Menachem Kellner, Maimonides on Human Perfection (Atlanta: Scholars Press, 1990). One may ask whether the omission here of an explicit reference to a third perfection (the intellect) from the purposes of the Torah-though the concept is found elsewhere in Maimonides-is an intended hint as to the exclusively social or pedagogical nature of the Torah. See also Abulafia's Or ha-Śekhel, 29 on the three perfections. See also Gad Freudenthal, "The Biological Limitations of Man's Intellectual Perfection according to Maimonides," in The Trias of Maimonides: Jewish, Arabic, and Ancient Culture of Knowledge, ed. Georges Tamer (Berlin: De Gruyter, 2005): 137-49, and chapter 8 note 60 below.

52 "Necessary and useful" refer to things that are intended for the masses although they are not necessarily true. This is the status of the commandments. See chapter 16 below for the passage from the epistle Mașref la-Kesef.

53 The image of the key is quite important in Abulafia's writing: he wrote several books whose title includes a reference to a key. See Idel, “On the Meanings of the Term 'Kabbalah,"” 67. Interestingly enough, according to a Jewish testimony related to early Islam, a prophet who was regarded as the anointed one claimed that he possessed the keys to paradise. See Patricia Crone and Michael Cook, Hagarism: The Making of the Islamic World (Cambridge: Cambridge University Press, 1977), $3-4$.

54 See the introduction to Mafteah ha-Hokhmot, 7. Nota bene: the key is necessary; however, at the same time, it is different in nature to the gate.

55 On this ideal in the Jewish Middle Ages, see Hava Tirosh-Samuelson, Happiness in Premodern Judaism: Virtue, Knowledge, and Well-Being (Cincinnati: Hebrew Union College Press, 2003).

56 Haśśagat ha-Šem is another version of Yedi'at ha-Šem, which is one of Abulafia's highest religious aims. This comprehension is expressed by the term haśśagah, which is a philosophical term for cognition. See also the quote from Sefer ha-Yašar in Appendix D below. See also chapter 5 note 195 above and chapter 8 note 80 below.

57 Sefer Hayyei ha-Nefeš, 15, corrected according to Ms. Munich, 408, fol. 10a:

והנה בראשית היצירה נכללו ג' מיני עבירות ע"ז ג"ע ש"ד, וכן בסוד המילה שלשה אלה, מפני שממנה ראשית בריאת המין

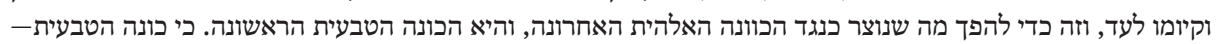

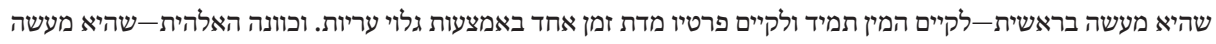

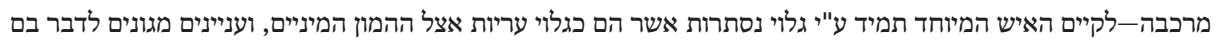

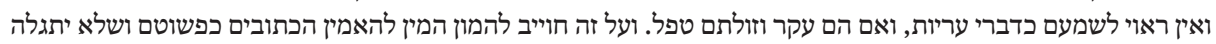

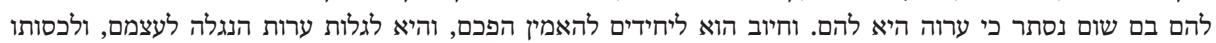

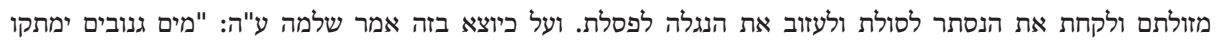

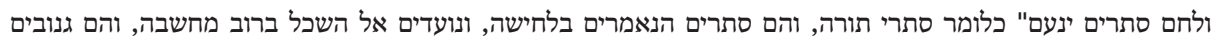

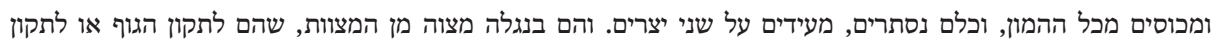
הנפש ההכרחיים או מועילים. הנה הנגלה מפתח לפתוח בו שערי הנסתר, והנה הוא מכלל הנסתר בעים בסוג ולא במין, 
Abulafia uses a basic pun: incest, 'arayyot, is also referenced in some Rabbinic texts as gillui 'arayyot, literally meaning the uncovering of the genitals, and by extension, the uncovering of sexual relations of a forbidden nature. ${ }^{58}$ In Hebrew, uncovering also means disclosure, which means that the revelation of the secrets of incest may be regarded by the vulgus as being shameful. Thus, the same act may be regarded as sublime by the elite and shameful by the multitude. ${ }^{59}$

To formulate it differently: what is good for the species-namely, its genetic continuity that is attainable only through sexual relations (which is conceived as the intention of the account of creation, or the natural intention)-is considered in this context as inferior to the account of the chariot (which is concerned with the special wise or distinguished individuals whose continuity depends on intellectual activity) that is described as fulfilling the ultimate divine intention. ${ }^{60}$ Secrecy is, therefore, not a matter of ineffability, but of the need to provide different audiences with a variety of diverse information that is appropriate to their different capacities of understanding.

Such a stringent attitude towards other people is found in one of Abulafia's commentaries on his prophetic books:

It is incumbent on every illuminated [person] who wishes to prophesy that he regard in his eyes and heart each and every individual of the "men of the land," ${ }^{61}$ the foolish ones, as if they are apes and all their deeds are like the deeds of the parrots and their thoughts are like the thoughts of the šenhavim, ${ }^{62}$ and these are sorts of beasts and it is appropriate to bless on them "blessed is He Who changes the beings," ${ }^{33}$ and all three [of them] are kinds of apes and all their acts are

מפני תקון הגוף היא הכנה לתקון הנפש ותקון הנפש הכנה לשלמותה האחרון אשר אליו תכלית הכוונה האלהית האחרונה,

והיא השגת השם.

See also my "The Kabbalistic Interpretations of the Secret of Incest in Early Kabbalah," 158-59, and “"In a Whisper,”" 481-82. See Wolfson, Abraham Abulafia, 191-93, 200, whose analysis is, in my opinion, quite problematic because he presupposes that the performance of the commandments is essentially related to the hidden layer, not merely to the study of the words expressing these commandments. See, especially, his discussions on 191, 197, and 200. The terminology related to the term "intention" is once again Maimonidean.

58 An interesting parallel is found in Sefer Ner Elohim, an anonymous treatise from Abulafia's circle, ed. Gross (Jerusalem: 2002), 48: וכל מי שמגלה סתרי תורה למי שאינו הגון להיותם נגלים לו, הוא מגלה עריות. 59 See also Oșar 'Eden Ganuz, 2:9, 289.

60 Abulafia is more explicit than Maimonides was as to the existence of the third divine intention; namely, the perfection of the intellect. See his Mafteah ha-Hokhmot, Ms. Parma, de Rossi 141, fol. 7a, 21-22; Idel, Language, Torah, and Hermeneutics, 109-10; as well as chapter 8 note 51 above. On the topic of distinguished individuals, see the detailed discussion in chapter 21 below.

61 A Hebrew expression for ignoramuses.

62 Sic! In Hebrew, however, this is a term related to elephants or their ivory, having nothing to do with apes, as Abulafia asserts, quite surprisingly, in the following phrase. This is a rare case in Abulafia's writings where a clear misunderstanding of a Hebrew term is found.

63 Cf. 1 Kings 10:22 and BT, Berakhot, fol. 58b. Compare also to Rabbi Abraham ben Isaac Bedershi, Hotam Tokhnit, ed. Gavriel Pollak (Amsterdam: Levison and Proops, 1865), 1.24, 265. 
imaginative ${ }^{64}$ and the person who is found with them is like someone who is alone in a forest knowing that there is no one like him and that his body is endangered by those evil beasts that are found in the forest all the time. But they have no power over his soul, since it is the intellective soul that remains after the life $\mathrm{e}^{65}$ of this world. But because he is found among them and he is from their species as one of them, and given the fact that his intellect transcended their species, he was [nevertheless] separated from them and became another species, a divine one after being human. ${ }^{66}$

What is obvious here is the stark distinction between the elite and the masses that follows Maimonides, his philosophical sources, and perhaps his teacher, Rabbi Hillel of Verona. ${ }^{67}$ Abulafia does not even hint here at the other distinction between Jews and Gentiles. I can scarcely imagine a more elitist anthropology than this one, which had quite an impact on Abulafia's understanding of religion and esotericism altogether. However, let me emphasise that this is not an exceptional text, as its content reverberates in his later writings as well.

Abulafia recommends that one should "be separated from the people of the earth"; "all the people should be in his eyes as beasts and animals and birds"; the assumption that only those who are similar to the elite figures possess "selem and demut, which are the masters of the Torah and the keepers of the commandments in truth." ${ }^{68}$ In the vein of a Straussian reading, I propose that we be sensitive

64 Or imitative. Compare to a similar depiction of apes in his Šomer Mișwah, 42.

65 חיות. I see no reason to translate this term as "beasts" here, as I did earlier in the same text. 66 Commentary on Sefer ha-Meliș, Ms. Roma, Angelica 38, fol. 9a, 19-20:

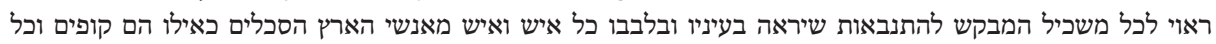

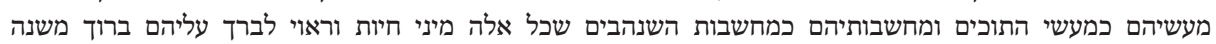

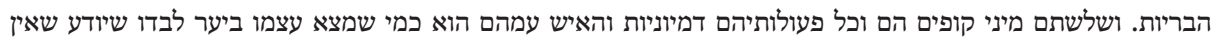

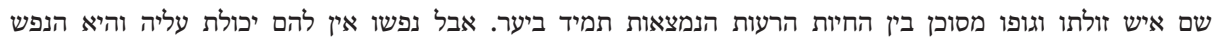

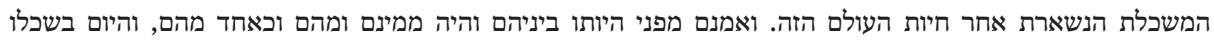

נתעלה ממינם ונתייחד מהם ושב מין אחר אלוהי אחר היותו אנושי. On this passage see Idel, Studies in Ecstatic Kabbalah, 16. See also Ḥayyei ha-Nefeš, 121. For the possibility of the divinisation of human beings, see also Al-Fārābi and Hillel of Verona, Tagmulei haNefeš, 56, Sermoneta's footnotes there, and ibn Falaquera, Sefer ha-Ma'alot, 28. On "apish" behaviour, see Abulafia's Mafteah ha-Ra'ayon, 68. For the transformation into "sons of God" (that is, some form of angel), see the anonymous text found in Ms. Jerusalem, NLI 1303, fol. 70a, which is found just before what I consider to be the introduction to his early commentary on the Guide, Sefer Ge'ulah. Let me point out the importance of several manuscripts, this being one of them, which contain a variety of secrets or disparate material from ecstatic Kabbalah, for understanding some topics in this Kabbalah but which have nevertheless been ignored in modern scholarship on Abulafia. See Idel, Studies in Ecstatic Kabbalah, 12-13; 27, note 63. In general, the importance of the traditions found in collectanea of Kabbalistic secrets found mostly in manuscript for understanding the eclectic aspects of Kabbalistic literature needs a more detailed assessment. See also Oșar 'Eden Ganuz, 2:7, 267.

67 Guide of the Perplexed, 1:14.

68 Oșar 'Eden Ganuz, 3:9, 364: 
to the potential hint found in the adverbial form be-emet, "in truth," since it may reflect a distinction between the performance of the commandments on the one hand and the study of the letters by means of which the commandments are formulated on the other, the latter being considered superior to their performance. Moreover, I assume that the image (selem) is paralleled by the Torah, while demut corresponds to the keeper of the commandments, an issue to which we shall return to in some detail in chapter 10.

A question that should be addressed in the context of this passage is whether this transformation of the human into the divine, which is a form of apotheosis or even theosis, concerns only the intellectual faculty or whether it also concerns the human imagination. Since I have not found the assumption that God possesses some form of imagination, transformation, in my opinion, means getting rid of this faculty.

We learn from another passage from the same commentary on the Guide's secrets that anthropology and the alleged structure of the canonical texts are intertwined:

The [biblical] verse bears two topics together, and even supports the plain sense, when its first words are brought together with the last words, more than the hidden; when the hidden topic is understood by the perfect intellect, ${ }^{69}$ [that is] a demonstrative and Kabbalist-religious one, we should not care about the connections between the words in the plain sense. Those [connections] came only in order to [profoundly] deepen the secrecy ${ }^{70}$ that emerges out of it and to cover the hidden [sense] from the multitude of the sages of the plain sense ${ }^{71}[\ldots]$ the hidden [things] are divine topics and the plain sense [things] are human topics. ${ }^{72}$

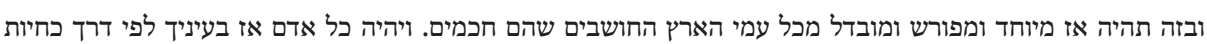

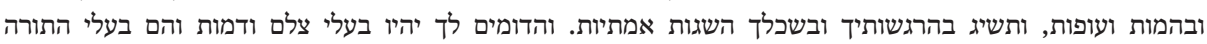

ושומרי המצוה באמת.

On șelem and demut in Maimonides, see Marvin Fox, Interpreting Maimonides: Studies in Methodology, Metaphysics, and Moral Philosophy (Chicago: University of Chicago Press, 1990), 156-73. Compare, however, to the view of Wolfson, Through a Speculum That Shines, 23: "The morphological resemblance between the divine and human image, rooted in biblical thinking, played a central role in the subsequent development of Jewish mysticism in all of its stages." On the rationales of the commandments in Maimonides, see Yair Lorberbaum, "'What Would Please Them Most is That the Intellect Would Not Find a Meaning for the Commandments and the Prohibitions': On Transcending the Rationales of the Commandments-A Close Reading of the Guide of the Perplexed III 31" [Hebrew], Da'at 77 (2014): 17-50.

69 "Perfect intellect" is an important concept for Abulafia, since he was concerned with removing the imaginative power in order to attain the highest type of experience, as we shall see below.

70 Or the hiding: lehaflig ha-hester.

71 See also Mafteah ha-Hokhmot, 101. On the oxymoronic phrase "multitude of sages," see also Abulafia's Or ha-Śekhel, 39, and the introduction to Mafteah ha-Hokhmot, 6, which is quoted as a motto. 72 Hayyei ha-Nefeš, Ms. Munich, 408, fol. 9b, 12:

ואע"פ שהכתוב סובל שני העניינים יחד, ואולי סובל הנגלה יותר מן הנסתר לכשיוקשרו דבריו הראשונים והאחרונים

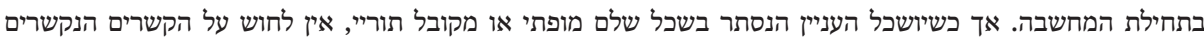

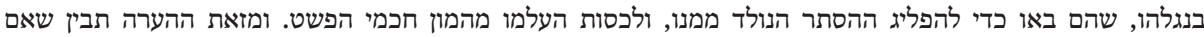

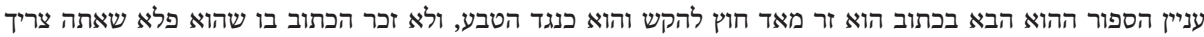


The plain sense covers the hidden one by giving the impression that the purpose of the biblical verse is a narrative that can also be understood by the vulgus. In a way, this sense only dissimulates the hidden truth, at least giving it some form of camouflage. In other words, the more the plain sense is understood, which means the more conspicuous the mythical elements are, the less it conveys or indicates of the presence and true meaning of secrets. Thus, it lures the reader to believe in this plain sense.

Just as he regards the plain sense as refuse in comparison to the secret sense, which he describes as fine flour, here the plain sense does not play a significant role in the religiosity of the Jewish elite as Abulafia understood it. This we may learn from one of the concluding pages of his Oșar 'Eden Ganuz:

But in the event that we attribute them to Him, blessed be He, as we attribute them to us, we would be lying ${ }^{73}$ as far as both of us are concerned, ${ }^{74}$ since there is nothing in our thought and in our words, but all are imaginations and parables that we resorted to since they generate fear and awe in the heart of the multitude, which does not discern that they are the utmost limit of lowness. $^{75}$

This is one of the most distinct pedagogical-political statements made in Judaism before Spinoza. Abulafia evinces what I would designate as a disjunctive approach that creates a sharp tension between the two senses of the sacred scripture, expressed in quite strong terms. This statement is no doubt part of the reason for the persecutions he suffered.

Abulafia's rather deterministic anthropology is part of this disjunctive attitude. Indeed, he was ready to take chances, even when he was aware of the high price he might pay for his opinions. For example, in Oșar 'Eden Ganuz, his longest Commentary on Sefer Yeșirah, he describes his disclosure of the secret of the twenty-

לדעת נסתרו, על כל פנים אחר אשר אין מציאות אל נגלהו לא במרגש ולא במשכל, וראוי שתשליך ממנו המדומה ושתשכיל ענינו ומה הכוונה אליו [...] הנסתרות הם עניינים אל אלה פליים, והנגלות הם אנושיים. On the secrets of the tablets of the Law, see Oșar 'Eden Ganuz, 1:3, 192.

73 This is reminiscent of the Shi'ite concept of dissimulation, or taqiyya. Cf. Etan Kohlberg, "Some Imāmī-Shīì Views on Taqiyya," JAOS 95 (1975): 395-402, and Etan Kohlberg, "Taqiyya in Shīî Theology and Religion," in Secrecy and Concealment: Studies in the History of Mediterranean and Near Eastern Religions, eds. Hans. G. Kippenberg and Guy G. Stroumsa (New York: Brill, 1995): 345-60. However, despite the important role of the hypostatic intellect reminiscent of Abulafia's śekhel ha-po'el, early Shi'ite esotericism dramatically differs from Abulafia's.

74 The Hebrew is not so clear here.

75 Oșar 'Eden Ganuz, 3:10, 386:

ואמנם אצלו ית' כשניחסם אליו כהתייחסם אלינו נשקר בין שנינו כי אין הדבר במחשבתינו ולא בדברינו אבל הכל דמיונות

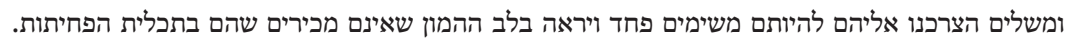
For the nexus between fear and the multitude, see also Mafteah ha-Hokhmot, 76:

מפני שיירא מאלהיו תמיד כל ימי חייו עת אחר עת לפי ההמונות.

"Since he will fear his God always, all the days of his life, time after time, as the multitude does." 
two fundamental letters and the combination of letters as if they were unknown by Gentiles as well as forgotten by Jews in the last generations:

I have a strong need and necessity [generated by] the motion of desire to write here the truth of the thing without fear of punishment, and to announce this immense secret in a manner that is entirely explained and interpreted, so that you ${ }^{76}$ and those like you will not be deprived of the knowledge of this wondrous secret, which is the stake on which everything depends. I do so despite the fact that I knew what things would happen to me and to my book because of its disclosure [and] because of them, I will not refrain from saying what we have been taught from heaven ${ }^{77}$ and what we have received from the best of the prophets and sages, blessed be their memory, who received it from God mouth to mouth. ${ }^{78}$

What is the secret hinted at concerning the letters and their combination? And why does Abulafia imagine that he will be persecuted because of the disclosure of this secret? I hope to be able to answer these questions later in this study when I deal with Abulafia's concept of language. Now, I would like only to note that this passage contains a second explicit recognition that he is breaking the spell of secrecy despite his awareness of the dangers of doing so. A third instance is better known in scholarship and has to do with conversations Abulafia had with a Christian who was so fond

76 Namely, his faithful student, Rabbi Sa'adyah ben Isaac Sigilmasi, to whom the book is dedicated. 77 A very similar phrase is found in Ner Elohim, a treatise from Abulafia's school, 96:

ואמנם אני לא מפני זה אמנע מלומר בו מה שהורוני מן השמים.

This close affinity in the formulation shows that the confidence in the content of revealed knowledge prevailed over the fear of the negative reaction of the surrounding populace. On the resort to the phrase "we were taught from heaven" in the twelfth century, see Isadore Twersky, Rabad of Posquières (Cambridge, MA: Harvard University Press, 1962), 291-97. In general, Abulafia and his followers were less concerned with the conservative approaches in Rabbinic Judaism. Compare, however, Scholem's totalising statement that "all mysticism" has a conservative and a revolutionary dimension that are complementary. Cf. his “Mysticism and Society,” Diogenes 15 (1967): 15.

78 Osar 'Eden Ganuz, 1:2, 51:

על כן יש לי צורך גדול והכרח הנעה חשקית לכתוב פה אמתת הדבר הזה מבלי פחד עונש. ולהודיעך זה הסוד המופלג כולו

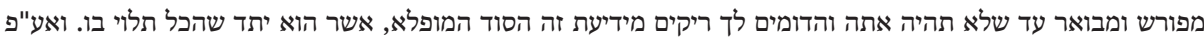

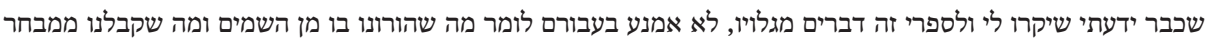

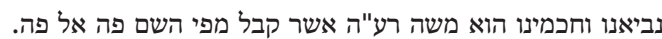

For another translation and analysis of a longer passage that includes this text, see my Language, Torah, and Hermeneutics, 47-48. Compare this passage to the text from the same book, Oșar 'Eden Ganuz, 1:3, 110, translated above, as well as to the short but conclusive statement in his Commentary on Sefer Yeșirah, 3: "They learned the order of all the known languages from Sefer Yeșirah, in a very hidden manner” (שלמדו סדר כל הלשונות הנודע מספר יצירה בצורה נעלמת מאד).

On the order of the languages, see also Commentary on Sefer Yeșirah, 4. This means that the book that deals with combinations of letters as related to cosmogony was understood as secretly hinting at the technique of generating languages. The alleged hidden aspect of this book was understood by Abulafia as dealing with the account of the chariot, which in this specific context means the practice of combinations of divine names. On the secrets of languages (in this case, he uses the term seter), see Or ha-Śekhel, 33. 
of him that he was ready to accept "secrets of the Torah" from the ecstatic Kabbalist. ${ }^{79}$ Abulafia hints that he gave them to him.

The nature of the secrets of the Torah has not been discussed by scholars, but this can be gleaned from the immediate context: Yedy'at ha-Šem, the gnosis of the divine name. ${ }^{80}$ This means that Abulafia was ready to initiate a Christian into the highest form of secret Jewish knowledge, according to his own view of secrecy. This is the reason why he immediately added "there is no need to reveal the issue of the Gentile any longer." He well-understood that his comportment was far from being one that was acceptable to many Jews, given the explicit Rabbinic dictum that it was forbidden to teach Torah to a Gentile, much less its secrets. ${ }^{81}$ Whether there is indeed more to this affair that he did not disclose remains a question that cannot be answered from the scant information we have.

Abulafia claims that he is the inheritor of an ancient secret lore that has been forgotten, which is a common claim of other esotericists of the Middle Ages, especially Maimonides, as well as Jewish philosophers and Kabbalists. At the same time, however, he claims that he receives messages from above concerning non-exegetical matters. Thus, exegesis is not the sole channel for reaching the secrets; there is an alternative avenue that is open to pneumatics and to both pre-existing and new secrets. Esotericism, therefore, is not just a matter of preserving ancient secrets, or a closed type of knowledge. It may turn into an open type of knowledge which was conceived to be revealed and could then be inserted into the interpreted texts by means of what is today called hermeneutics (eisegesis).

The political esotericism of the Neo-Aristotelian philosophers is the most important source for the secrets that constitute Abulafia's profound conceptual structure. However, it should be emphasised that Abulafia was also exposed to other forms of esotericism already found in the Jewish sources with which he was acquainted, such

79 See Mafteah ha-Hokhmot, 89-93, a passage referenced and sometimes analysed by Scholem, Major Trends in Jewish Mysticism, 129; Hames, Like Angels on Jacob's Ladder, 102-4; and Wolfson, "Textual Flesh, Incarnation, and the Imaginal Body," 198-99.

80 On this phrase, see chapter 5 note 195 above and chapter 8 note 56 below. On the different understandings of the divine name in Jewish traditions before Abulafia, including Maimonides and the early Kabbalists, see Haim Hillel Ben-Sasson, YHWH: Its Meanings in Biblical, Rabbinic and Medieval Jewish Thought [Hebrew] (Jerusalem: Magnes Press, 2019), as well as Lorberbaum, Dazzled by Beauty, 126-27, 148-49.

81 BT, Hagigah, fol. 13a, and the quote in the Zohar, 3 fol. 73a. Compare, however, Wolfson's claims that for Abulafia, "the promotion of this knowledge is dependent on the inherently incomparable comportment of the Jew." See his "Textual Flesh, Incarnation, and the Imaginal Body," 200, note 41. Note the resort to the singular when describing "the Jew": all Jews are portrayed as "inherently" displaying the same comportment and Abulafia is therefore seen as behaving like all the others! This is an example of what I would call compact Judaism, a scholarly fiction of homogenous Jewry which neglects distinctions between different Jews on the one hand and, in this case of the subversive nature of Abulafia's behaviour, his persecutions by other Jews and his unique Kabbalistic thought on the other. The same approach can be seen in Wolfson's earlier Abraham Abulafia, 224. See also chapter 21 note 340 below. 
as the Ashkenazi literature, some of which may be described as esoteric; such, for example, are the writings from the circle of the Qalonymus family, where a scriptural type of secrets is predominant, and similarly the astrological esotericism of Rabbi Abraham ibn Ezra. Furthermore, he was familiar with the esotericism of the theosophical-theurgical Kabbalists, who were mainly concerned with the intradivine powers, the affinities between them, and the performance of the commandments, as well as the various esoteric understandings of the transmigration of souls. ${ }^{82}$ Abulafia was also acquainted with the so-called Hekhalot literature, as well as with some of the Jewish magical literature, though their influence is less evident. ${ }^{83}$ Another type of esoteric tradition, the Neo-Pythagorean one, was also known to Abulafia, though in quite a fragmentary manner. An important example of this will be presented in Appendix C.

However, merely revealing the precise sources that he was acquainted with or which were influential on his views is not sufficient for gaining a better understanding of Abulafia. Rather, it is important to determine the type of esotericism that informed Abulafia's thought and that prevailed over the others. In my opinion, the political esotericism that was concerned with naturalistic and mentalistic views constituted the most important source for Abulafia's own esotericism, and all the others are presented in order to facilitate the hiding or divulgence of his secrets.

There were indeed multiple sources, but what is conceptually quintessential is the establishment of the central point of a certain profound structure-if such a centre can be detected-and the nature of the material that remained on the periphery of his thought. In addition, there is also the question of what the available choices between his sources were and which of them shaped his attitude towards those sources. This is a matter of the statistical occurrence of terminology. In this case, the recurrence of Neo-Aristotelian nomenclature is paramount, but statistics alone are certainly not enough, though they may indicate the gist of the fabric of his thought. He was attracted to Maimonides's Neo-Aristotelianism more than any of the other Kabbalists in the thirteenth century, a fact that sharply distinguishes him from them, including his disciple Gikatilla, who changed his Kabbalistic approach later in his life.

Moreover, the many references to the existence of the esoteric level of the Torah did not address the specific content of those esoteric issues. Indeed, they constitute more of a rhetoric of esotericism than a revelation or indication of esoteric issues. To understand the way in which Abulafia operated, according to Wolfson, one should assume that this is a case of "the secret that cannot be kept." 84 Given the possibility that a Kabbalist's rhetoric is also a meaningful fact, the question is whether he had some secrets that he did not reveal, but rather kept to himself. In the following chap-

82 See Idel, "Commentaries on the Secret of 'Ibbur in 13th-Century Kabbalah."

83 See Idel, "Hekhalot Literature, the Ecstatic-Mystical Model and Their Metamorphoses," $191-202$. 84 Abraham Abulafia, 52. Compare also his "The Anonymous Chapters of the Elderly Master of Secrets: New Evidence for the Early Activity of the Zoharic Circle,” Kabbalah 19 (2009): 152. 
ter, I will address this issue by providing a positive answer. If my positive answer is correct, at least in some important cases (and there was a layer of secrets that was hidden), it may provide a picture of Abulafia's thought that differs from the many scholarly accounts we have about him. It seems that the ecstatic Kabbalist was an esoteric thinker, and quite an efficacious one at that. His secrets have not been decoded by many scholars writing about him over a century and a half, as we shall see immediately below.

\section{Was Abulafia a Particularist Kabbalist?}

In an age of political correctness that has deeply permeated the language of scholarship, particularism has very bad overtones, especially in academic circles, unlike its opposite pole, universalism. In fact, it is difficult to detect universalistic religious approaches in general, since each universalism is based upon inbuilt assumptions that are sometimes as particularist as the particularist ones. They are conditioned by specific historical circumstances, linguistic biases, and political conjectures. In the following pages, I shall attempt to refer to these two approaches without judging them or giving preference to one or the other, ${ }^{85}$ especially given the fact that the limited universalist approach to be discussed in this chapter is highly restrictive and quite elitist, as it looks down on unintelligent persons. Thus, the claim of Abulafia's universalism is, in my parlance, not to be seen as a judgmental statement.

It is obvious that traditional Jewish thought, anchored in a much more nationalist proclivity, was likewise much more inclined to particularism. However, some distinct tendencies towards universalism can be discerned in a few Rabbinic texts, and especially in Maimonides, ${ }^{86}$ whose books were one of Abulafia's major sources. Moreover, this more universal approach is found in the philosophical sources he studied: Aristotle, Al-Fārābī, and Averroes, to name a few. I claimed above that the philosophical sources for Abulafia's early studies should also be seen as decisively formative for his thinking in the Kabbalistic period, in a manner that remained much more universalistic than some Abulafia scholars have imagined.

85 Compare, however, the approaches of the contributors in Raphael Loewe, ed., Studies in Rationalism, Judaism \& Universalism in Memory of Leon Roth (London: Routledge and Kegan Paul, 1966). 86 See Kellner, Maimonides' Confrontation with Mysticism, 14-15, 250-64; Kellner, Science in the Bet Midrash, 249-346; Menachem Kellner, They Too Are Called Human: Gentiles in the Eyes of Maimonides [Hebrew] (Ramat-Gan: Bar-Ilan University Press, 2016), 21-38, 44-51; Alexander Altmann, "Maimonides and Thomas Aquinas: Natural or Divine Prophecy?” AJS Review 3 (1978): 1-19; Kraemer, "Naturalism and Universalism in Maimonides' Political and Religious Thought." For his Rabbinic background, see Marc Hirshman, "Rabbinic Universalism in the Second and Third Century," HTR 93, no. 2 (2000): 101-15, and his Hebrew book Torah le-khol Ba'ei 'Olam (Tel Aviv: Ha-Kibutz Ha-Meuhad, 1999). 
The relevance of philosophical sources for Abulafia's Kabbalah can be put into relief by discussing the manner in which we should understand his treatments of an important Rabbinic particularist myth. This has to do with the assumption that the pollution, or poison, that the serpent injected into Eve as he had sexual relations with her was removed from the Israelites on the occasion of the Sinaitic revelation. Some scholars consider that the manner in which this myth was formulated provides an antidote to the Christian conception of the ongoing effect of original sin, which seeks to emphasise the centrality of the salvific role played by Jesus in the process of redemption. The Gentiles, so this Rabbinic myth asserts, not being present at the revelation on Mount Sinai and consequently not receiving the Torah, remained contaminated with that primordial pollution. ${ }^{87}$

This Rabbinic myth is indubitably part of the more general idea of the Jews as a chosen people forged in the Hebrew Bible, for which the revelation of the Torah on Mount Sinai is the most dramatically formative event. ${ }^{88}$ Given the traditional view that the Sinaitic revelation was a unique act in history, the stark division between Jews and Gentiles is conceived as a dramatically important aspect in Rabbinic anthropology and constitutes a final separation that can only be overcome by conversion to Judaism.

The Rabbinic discussion presented in the name of Rabbi Yohanan had some reverberations in medieval Jewish thought, including in some philosophical and Kabbalistic writings. ${ }^{89}$ However, it seems that none of the medieval writers referred to it as many times as Abulafia did. To judge solely on the basis of the mere occurrences of quotations from Rabbinic sources in Abulafia's writings, there may indeed be no

87 See BT, Shabbat, fol. 146a; BT, Yebamot, fol. 103b; BT, 'Avodah Zarah, fol. 22b. On Genesis 3, see Yalqut Šim 'oni, paragraph 247; 28, paragraph 28; 31, paragraph 130. On this myth, see Urbach, The Sages: Their Concepts and Beliefs, 1:427-28, 553; Sharon Faye Koren, Forsaken: The Menstruant in Medieval Jewish Mysticism (Waltham: Brandeis University Press, 2011), 89-90; and Elliot R. Wolfson, Venturing Beyond: Law and Morality in Kabbalistic Mysticism (Oxford: Oxford University Press, 2006), 4041; and on Abulafia, see 65, note 203. See also chapter 9 note 93 below. For the possible Zoroastrian background, see Koren, Forsaken, and, in more general terms, Jamsheed K. Choksy, Purity and Pollution in Zoroastrianism: Triumph Over Evil (Austin: University of Texas Press, 1989).

88 On the topic of the chosen people, there is a vast bibliography. Close to our topics are the studies by Raphael Jospe, “The Concept of the Chosen People: An Interpretation," Judaism 170, vol. 43 (1994): 127-48, and Kasher, High above All Nations, passim.

89 See Maimonides, Guide of the Perplexed, 2:30, Pines, 2:357, and Wolfson, Venturing Beyond. See also Kellner, Maimonides on Human Perfection, 76, note 47; Menachem Kellner, "Monotheism as a Continuing Ethical Challenge to the Jews," in Monotheism and Ethics, ed. Yitzhak Tzvi Langermann (Leiden: Brill, 2012): 80-81, note 18; Esti Eisenmann, “The Sinaitic Revelation in Maimonides's Thought" [Hebrew], in The Bible and Its World, Rabbinic Literature and Jewish Thought, eds. Baruch Schwartz, Abraham Melamed, and Aharon Shemesh, vol. 1, Iggud-Selected Essays in Jewish Studies (Jerusalem: World Union of Jewish Studies, 2008), 322-62; and Davidson, Maimonides: The Man and His Works, 346-47. 
substantial difference between Abulafia and the particularist view of the Rabbis or of other Kabbalists. ${ }^{90}$

However, such an assumption would be based on a superficial reading of the sources, since Abulafia offered his own quite idiosyncratic interpretation of them and even explicitly criticised them more than once. What counts in this specific case and others is not the mere fact of the occurrence of a quotation, but the specific meaning that the author attached to it; namely, the type of interpretive register used in interpreting it. It is even more incumbent on a serious scholar to discern the fact that he is actually criticising the ideas found in the quoted passage..$^{91}$ Indeed, Abulafia refers to the Rabbinic statement, writing immediately afterwards:

The secrets of incest are the serpent's intercourse with Eve, who is an adulterer, and it injects its pollution into her. And Israel that stood in front ${ }^{92}$ of Mount Sinai, [their] pollution ceased, and the Gentiles who did not stand on Mount Sinai, their pollution did not cease. And this is a great matter that does not need an interpretation, since it is obvious for the illuminati that the Torah is the reason for the life of the world to come. ${ }^{93}$

90 As indeed Wolfson claims in Venturing Beyond, 65.

91 On this issue, see my "On the Secrets of the Torah in Abraham Abulafia," 418-30, where I already presented and analysed most of the pertinent sources in Abulafia's writings.

92 This is an unusual formulation, instead of "on." Is it a hint at the fact that the Israelites did not in fact stand on the mountain, as claimed in the Jewish traditional sources?

93 Hayyei ha-'Olam ha-Ba', 53:

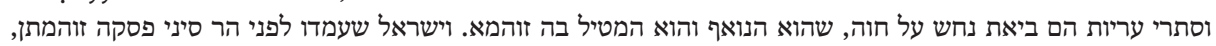

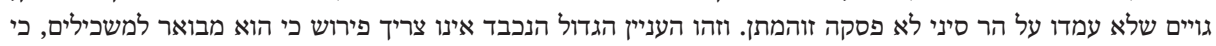

התורה היא סיבת חמדויי העולם הבאי לא.

On this text, see Idel, "On the Secrets of the Torah in Abraham Abulafia," 418-20, and Ogren, Renaissance and Rebirth, 82-83. The "world to come" is a traditional term that Abulafia understood as referring to the comprehension of the Agent Intellect. See the Untitled Treatise, Ms. Firenze, Laurenziana, Plut. II, 48, fol. 79b:

וכל מי שמשיג השגת השכל הפועל זוכה לחיי העולם הבא.

See also Hayyei ha-Nefeš, 92. On the quoted passage, compare to Wolfson, Venturing Beyond, 65, note 203; Wolfson, Abraham Abulafia, 194; and Sagerman, The Serpent Kills, 174-77. The two latter scholars addressed only this passage without providing any analysis, thereby ignoring the crucial contribution of the passages to be analysed below, which changes the picture dramatically. In Venturing Beyond, 65, note 203, Wolfson refers to only one of Abulafia's passages, the first one presented here, and even in this case, the text was misinterpreted in an opposite manner to the original, an example of a larger phenomenon I call the art of inversion. On the art of inversion in another case of ecstatic Kabbalah, see my Ben, 334-37; for another example related to Safedian Kabbalah, see Moshe Idel, "Ascensions, Gender, and the Notion of Pillars in Safedian Kabbalah,” Kabbalah 25 (2011): 60, note 11, with some other examples in my The Privileged Divine Feminine in Kabbalah (Berlin: De Gruyter, 2018), 117, note 507, 208, note 923, and in my forthcoming "Male and Female," as well as chapter 9 note 87 above and chapter 21 note 343 below. For the background of the more open Rabbinic statement under scrutiny here, see Israel Y. Yuval, "All Israel Have a Portion in the World to Come," in Redefining First Century Christian and Jewish Identities: Essays in Honor of Ed Parish Sanders, ed. Fabian E. Udoh (Notre Dame: University of Notre Dame Press, 2008): 114-33; and Eugene Korn, "Gentiles, the World to Come, and Judaism: The Odyssey of a Rabbinic Text," Modern Judaism 14, no. 3 (1994): 265-87. See also Hannah Kasher, High above All Nations. 
The nature of "the great matter" (an indication that should be taken seriously) and, moreover, that of the "secret" that is understood by the illuminati is not explained in the translated passage, but it can be elucidated by resorting to what is written only a few lines later, as well as in some other discussions on the same topic in Abulafia's writings. Following Maimonides, who elaborated at length on the meaning of the myth of Adam, Eve, and the serpent according to the stories found in the Hebrew Bible and the Midrash, ${ }^{94}$ though not concerning the removal of pollution, Abulafia allegorises the tale: the Aristotelian concept of form, Adam, is tempted by the imaginative faculty, the serpent, or, as he writes elsewhere, Satan, thus introducing the error that is matter, Eve. Following the Maimonidean tradition, the traditional conception of Sinai as a historical event has been identified with a mental experience which is interpreted as an atemporal, potentially recurring event, which is the most important register for Abulafia's Kabbalah. ${ }^{95}$

However, while in his Guide Maimonides refers quite succinctly to the Rabbinic passage on pollution and to the Sinaitic event as an antidote without elaborating on its possible meaning, Abulafia was obviously fascinated by the content of this discussion, returning to it; this fact allows for the decoding of his hint towards secrecy. Before turning to the other instances of dealing with the Rabbinic myth, let me refer to an interpretation of the quoted passage.

Referring to the passage from Abulafia's Hayyei ha-'Olam ha-Ba', Elliot Wolfson writes: "Abulafia depicts the ontic difference between Jew and non-Jew in terms of the Rabbinic legend that the Sinaitic theophany resulted in the removal of the filth with which the primordial serpent inseminated Eve from the Jews in contrast to the other nations." 96 The assumption of an "ontic difference" is indeed found,

94 Especially Guide of the Perplexed, 1:2, Pines, 1:23-26, and 2:30, Pines, 2:357. On the details involved in Maimonides's interpretation of the myth of the events in Paradise, see Pines, "Truth and Falsehood versus Good and Evil," 95-157; Stern, The Matter and Form of Maimonides’s Guide, 64-96; Sara KleinBraslavy, Maimonides's Interpretation of the Adam Stories in Genesis: A Study in Maimonides's Anthropology [Hebrew] (Jerusalem: Reuven Mass, 1986); Lawrence Berman, "Maimonides on the Fall of Man,” AJS Review 5 (1980): 1-15; Warren Zev Harvey, “Maimonides and Spinoza on the Knowledge of Good and Evil” [Hebrew], Iyyun 28 (1978): 167-85; Avraham Nuriel, Concealed and Revealed in Medieval Jewish Philosophy [Hebrew] (Jerusalem: Magnes Press, 2000), 110-18; and Heidi Ravven, "The Garden of Eden: Spinoza's Maimonidean Account of the Genealogy of Morals and the Origin of Society," Philosophy and Theology 13, no. 1 (2001): 3-47. On Maimonides's attitude towards Gentiles, see Kellner, Maimonides' Confrontation with Mysticism, 229-33, 238-64.

95 Sara Klein-Braslavy, Maimonides's Interpretation of the Story of Creation [Hebrew] (Jerusalem: Reuven Mass, 1987), 348; Schwartz, “To Thee Is Silence Praise," 162; and Gitit Holzman, "State, Religion, and Spirituality in the Thought of Rabbi Moses Narboni” [Hebrew], in Religion and Politics in Jewish Thought, 1:201-2. As Warren Zev Harvey pointed out to me, Moses Narboni develops Abulafia's insights regarding “the mountain." See also Ephodi on Guide, 2:30, and Abraham J. Heschel, God in Search of Man: A Philosophy of Judaism (New York: Farrar-Strauss, 1978), 146. In principle, this type of spiritualisation is compatible with the views of Franz Rosenzweig and Martin Buber.

96 Venturing Beyond, 65, note 203; 41, note 104, and his description of the "dualist tone" in "Textual Flesh, Incarnation, and the Imaginal Body,” 215. This passage does not prevent him from writing that 
however, not in Abulafia's passage, but only in the Rabbinic discussions and in those of their followers. What Abulafia himself had in mind was something entirely different, and he hints at the existence of a secret, an issue that was not taken into consideration by Wolfson's analysis. Indeed, this is a symptomatic example of ignoring the possibility that there was a secret in this specific Kabbalist's discourse, even when he explicitly mentioned its existence. Consequently, this neglect caused his interpreters to miss or invert his hidden intention.

Abulafia elaborates the secret hinted at in the last passage in several other places in much more explicit terms. This preponderance of references to this secret has been ignored in the discussion of Abulafia's view on the topic. When dealing with the magical texts that were widespread and used by some unnamed contemporary Rabbis, whom we may assume were mainly of Ashkenazi extraction and whom he sharply condemned, ${ }^{97}$ Abulafia issues the following evaluation:

They have polluted brains, which the serpent injected the pollution into: and they did not stand on the Sinai mountain, and this is the reason why their pollution did not cease. This is the reason why anyone ${ }^{98}$ who wants his pollution to cease should stand on Mount Sinai ha-senyry, harsynay, harsnyy, which puts the halter in the mouth of the power of desire, and then he will be saved. ${ }^{99}$

The depiction of the Rabbis who were interested in magic as persons who did not stand on Mount Sinai and the description of their brains as subsequently still polluted is quite explicit and sharp; it seems that Abulafia envisioned the Sinaitic revelation as having nothing to do with the catharsis related to people possessing a certain genetic quality in a given historical moment. Here, the allegorisation of the experi-

he envisioned Abulafia in universalist terms or from claiming that I distorted his views when I described his reading of the ecstatic Kabbalist as particularist, as we shall also see in chapter 9 note 116 below. For the existence of an alleged “ontological barrier” that Abulafia "erected" between Kabbalists and Christian sages, see Sagerman, The Serpent Kills, 58.

97 See my "Abraham Abulafia: Between Magic of Names and Kabbalah of Names," 79-96; Kabbalah and Eros (New Haven: Yale University Press, 2005), 44; Mafteah ha-Ra'ayon, 23-24; and Sagerman, The Serpent Kills, 144.

98 Compare to the resort to the term Adam (man) in exactly the same context, in a text to be quoted immediately below.

99 Oșar 'Eden Ganuz, 3:7, 332:

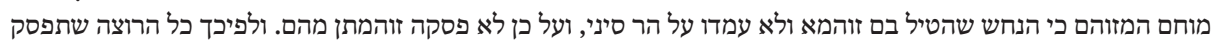

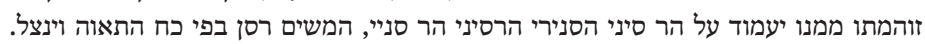
Interestingly enough, the same exact phrase, moham mezoham, occurs in another critique of those who use magic and persons who were seen to belong to a Jewish elite in Northern France two generations before Abulafia. See Joseph Schatzmiller, “For a Picture of the First Polemic on Maimonides's Writings" [Hebrew], Zion 34 (1969): 143:

כי עשו עצמם בעלי שם כנביאי האמת הידועים והמה אוילים משוגעים מלאי תעתועי מוחם מזוהם.

The more general similarity between this text and Abulafia's view has also been pointed out by Ram ben Shalom, "Kabbalistic Circles Active in South of France (Provence) in the Thirteenth Century" [Hebrew], Tarbiz 72 (2014): 596, note 117. 
ence on Mount Sinai is explicit: the ancient experience was conceived as an irreversible event in Rabbinic sources, but according to Abulafia, it may and should be repeated in the present.

The true meaning of the experience on Mount Sinai was, according to Abulafia, only a matter of restraint, a conclusion he reached by permuting the consonants of the Hebrew phrase הר סיני ("Mount Sinai") so that other combinations of letters emerge, two of which, הרסיני and הרסניי, contain the root RSN, which means "to restrain." 100 He then interprets this root in the more general context of both the Edenic and the Sinaitic myths: both situations are a matter of sexual restraint. When someone does so in the present, the possibilities of re-experiencing the Sinaitic and Edenic situations emerge.

The significance of these two different situations in the Hebrew Bible has been homologised, and the two consequently became atemporal and homologous events that in this discussion depend on sexual restraint ${ }^{101}$ and much less, if at all, on the divine decision to reveal something. We shall have more to say about Abulafia's specific view of the divine will in chapter 18 below. ${ }^{102}$ Moreover, it should be noted that in some places in his writings, Abulafia allegorises the concept of "mountain" in general, sometimes as imagination and sometimes as intellect. ${ }^{103}$

As a corollary to the above discussion, let me mention another example of Abulafia's radical allegorisation: he regarded some people, most probably Jews, as having not yet departed from Egypt; rather, these people were still working for the Pharaoh and labouring to produce bricks. ${ }^{104}$ In this way, the two major "historical" events that were imagined to have shaped Jewish religious history are understood as repeatable and directly relevant in the present for both the elite and the multitude. Like Maimonides, Abulafia would say that there are Jews who remained in Egypt as it is allegorically understood and who did not stand on Mount Sinai. The basic anthropological unit of the biblical/Rabbinic literature, the Jewish nation, is not operating here. Rather, it is the individual who stands at the centre of the allegorised events. As with Maimonides's allegorical approach, the dramatic attenuation of the uniqueness of the formative historical events in the biblical/Rabbinic imaginaire is coupled with

100 Abulafia was probably influenced by a dictum attributed to Plato: "Prayer is the halter of the appetitive soul," which was also discussed on several occasions by Rabbi Joseph ibn Kaspi. See his Commentary on Proverbs in 'Aśarah Kelei Kesef, 1:17: התפילה רסן נפש המתאווה.

101 It should be mentioned that sexual sin is the very starting point of sin, and that zohama' (pollution) means "seminal emission" in other contexts in Abulafia's discussions. On the revelation of the Torah as a non-temporal event, see his Imrei Šefer, 134, where the First Cause and the Agent Intellect are related to this event.

102 Let me point out that it is not asceticism that Abulafia is hinting at; this is a call for restraint. See Idel, The Mystical Experience, 143-44.

103 See Idel, The Mystical Experience, 100-103.

104 Oșar 'Eden Ganuz, 2:7, 267:

וידוע כי מי שלא יצא ממצרים הוא עובד לפרעה ולמצרים ועדיין הוא עושה חמר ולבנים ונטבע בם. 
the attenuation of the subject matter of those events; namely, the Jews as a corporate personality.

However, the following passage from the same book by Abulafia is no less radical. Addressing the Rabbinic view, he writes:

And as it was said in the account of creation about the prostitute woman who was allured by the serpent, it had sexual intercourse with her and injected her with its pollution. But for Israel that stood on Mount Sinai, the pollution did not cease, and in order to find a way to stop the pollution, all the [three] books [attributed to King Solomon] were written. ${ }^{105}$

In this instance, Abulafia flatly contradicts one of the most cherished formulations that informed the national myth: in his opinion, the primordial serpentine pollution, if taken literally, was not removed at all, or at least not entirely, from Jews or Gentiles. The attempt to remove the pollution, according to Abulafia, is part of the much later literary project of King Solomon, who used a series of parables with the intention of combating the continuous impact of the mythical pollution. Implicitly, the Torah and commandments are seen as insufficient for this purpose; it is the wisdom of the later king that is found in his three books, written long after the Sinaitic revelation, that purifies the pollution. The task of wisdom, then, is imagined as a continuation of the attempt to purify what he imagined to be "the original pollution."

Wisdom, then, is a clue to the removal of the alleged pollution, which the traditional rites are incapable of accomplishing. This means, in my opinion, that according to Abulafia's esoteric views, the commandments have a political rationale, and the question that should be asked is whether they have an exclusively political purpose or whether they have additional ones as well.

To be sure, I do not assume that Abulafia adopted the myth of the Adamic sin verbatim in the terms that were elaborated in Christianity (original sin or the socalled Fall of Adam) or in the case of the Midrashic statement on serpentine pollution. Rather, in his mind, there is some form of perennial problem of human nature related to the inner powers that prevent the perfect type of cognition. This prevention occurs because of the existence of falsehood in the imaginative faculty. The historical status of the Sinaitic revelation therefore becomes quite problematic, though Abulafia does not openly question it here. As we shall see in chapter 14 below, according to two of Abulafia's other texts, Moses was a scribe who committed an older tradition to

105 Oșar 'Eden Ganuz, 1:3, 120:

כמו שנאמר במעשה בראשית על ענין האשה הזונה שפתה אותה הנחש ובא עליה והטיל בה זוהמא. וישראל שעמדו על הר

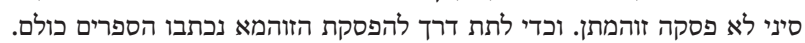
See an earlier version of the relation between the first man and the prostitute in Geo Widengren, "Primordial Man and Prostitute: A Zervanite Motif in the Sassanid Avesta," in Studies in Mysticism and Religion Presented to Gershom G. Scholem, eds. Ephraim E. Urbach, Raphael J. Zwi Werblowsky, and Chaim Wirszubski (Jerusalem: Magnes Press, 1967): 227-34. 
writing. Abulafia thereby mitigates both the paramount role of the revelation on the mountain and the uniqueness of this prophet for Maimonides. ${ }^{106}$

In a manner reminiscent of the last passage discussed, Abulafia writes in his Hayyei ha-Nefeš:

If the serpent has sexual intercourse with Eve, who is the prostitute woman, and she is the second wife of Adam, not the first, [who is called] Lilith, and the name of the second is Yomit, it will then inject the poison and the pollution when she eats from the tree of knowledge of good and evil and she feeds it to Adam, her husband, by dint of the serpent, and they will both die. And for a person ${ }^{107}$ who will stand on Mount Sinai, his pollution will cease and if the [serpent] bites him, he will not die, since he took from the tree of life and ate. ${ }^{108}$ Know that the name șelem is a wondrous parabolic one, and so the term demut, since the human comprehensions are three; namely, the sensual, the imagination, and the intellect. And the sensual connection is that of a man and his wife, and the imaginative connection is that between matter and form, and the intellectual connection is that between the intellect and the soul. The first two connections were linked and then separated, while the third, when it takes place, [then] persists forever. The Torah mentioned to the last two connections as imagination and intellect, provided they are secret matters, the one being natural-namely, demut-and the second one divine-namely, șelem -and solely these two alone are a divine act, but the third one ${ }^{109}$ is a human volitional act. ${ }^{110}$

The assumption of the existence of a secret in the biblical and Rabbinic accounts is again mentioned in an explicit manner. In a manner reminiscent of Maimonides's famous interpretation in the Guide, this is a strong typological interpretation that envisioned "Adam" not as the personal name of a figure belonging to the mythological story, but rather as the species. ${ }^{111}$ The concept of Eve (Yomit, the lady of day-time) versus Lilith (the legendary first wife of Adam, whose name, according to some Midrashim, refers to the night on the grounds of a pseudo-etymological relationship between Lilith/Lailah) is a nice example of a typological understanding based on dichotomies.

106 See Fraenkel, Philosophical Religions, 179-80.

107 Adam; namely, a human being in general, without mentioning whether he/she is Jewish or Gentile. See Stern, The Matter and Form of Maimonides's Guide, 64-66, 67, 68.

108 This contradicts the biblical version of the Paradise story.

109 Namely, the sensual one.

110 Hayyei ha-Nefeš, 1:1, 8:

אם יבוא נחש על חוה שהיא אשה זונה, והיא אשת אדם השנית לא הראשונה, כי שם הראשונה לילית ושם השנית יומית,

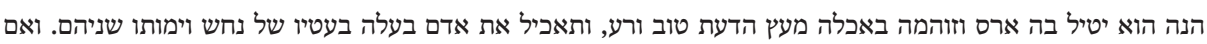

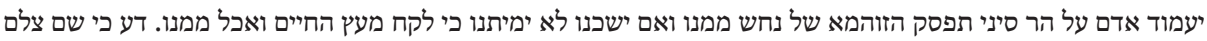

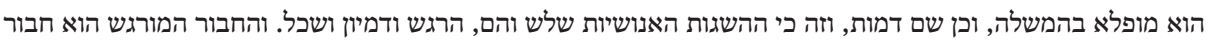

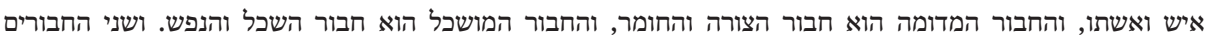

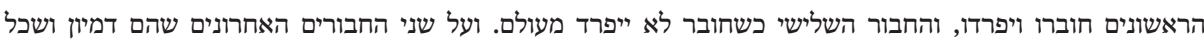

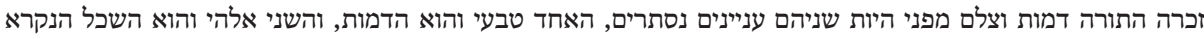

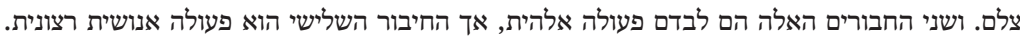

111 Guide of the Perplexed, 2:30, Pines, 2:335-59. See also ibn Kaspi’s commentary Maśkiyyot Kesef, ed. Werbluner, on the Guide 1:2, 13, and 1:14, 31, note 1. Ibn Kaspi claims that Adam did not exist and is only is an allegory for Moses. 
Again, the Edenic and Sinaitic experiences are homologised and imagined to be accessible in the present given their allegedly intellectual character. Though not explicitly contesting the historicity of these events, it obliterates their uniqueness, allegorising them as referring to experiences accessible to individuals at any time. Abulafia's interpretation, which indubitably has its Maimonidean source in the Guide, is reminiscent of Franz Kafka's fascinating reading of the Paradise events. ${ }^{112}$

The different forms of connection mentioned in the last quoted passage should be understood in the framework of this discussion, which describes the body's connection to the soul: the connection of the soul-which is understood as divine-with the intellect is described as "all" only after the soul has separated from the body and its faculties. ${ }^{113}$ This means that there is a process of universalisation attained by separation from the lower realms and the concomitant union with the higher, an issue that will be addressed in more detail in chapter 21. In the last quoted passage, the natural act is conceived as divine, at least implicitly, an issue to which we shall return in chapter 16.

Let me point out that the sexual connection between man and woman is here conceived as the lowest of the three, while in the theosophical-theurgical brand of Kabbalah, it is conceived as a symbol of the union between two divine powers, as is written, for example, in the anonymous and highly influential Holy Epistle attributed to Nahmanides, which was most probably written during Abulafia's generation and which deals with conjugal relationships. This is but one example of the stark divergence of Abulafia's thought from the main lines of theosophical Kabbalah.

In the introduction to his commentary on the Pentateuch, we find what is chronologically speaking the last significant treatment of the Rabbinic passage. Abulafia writes:

The matter of Adam, the serpent, and Eve, when taken as individuals according to their plain sense, is appropriate to laugh at at the beginning of thought, in accordance with the nature of humanity, and the Torah did not intent matters of laughter [...]. It is a fortiori necessary to interpret the words of the sage or of the prophets differently from their plain sense if a person's understanding does not accept them. And behold, our sages said in the Midrash that the serpent had intercourse with Eve and injected its pollution into her, and for Israel who stood on Mount Sinai, the pollution ceased, while the pollution of the Gentiles who did not stand on Mount Sinai did not cease. How is it possible that a person who thinks that this issue-that the serpent that is mentioned in the Torah will have intercourse with Eve-is according to the plain sense will be called wise? And behold, the Torah did not mention it. ${ }^{114}$

112 See his Parables and Paradoxes (New York: Schocken, 1966), 28-33, and compare to Moshe Idel, "On Paradise in Jewish Mysticism," in The Cradle of Creativity, ed. Chemi Ben-Noon (Ramot: Hod haSharon, 2004): 613.

113 Oșar 'Eden Ganuz, 1:1, 7-8. See also Or ha-Śekhel, 29.

114 Mafteah ha-Hokhmot, 44-45:

ענין אדם ונחש וחוה שאם ילקחו שלשת הפרטים האלה כפשוטם ראוי לשחוק מהם בתחלת מחשבה לפי טבע האנושות

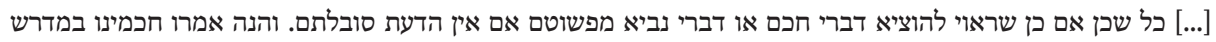
משבא נחש על חוה הטיל בה זוהמא, ישראל שעמדו על הר סיני פסקה זוהמתן, גוים שלא עמדו על הר סיני לא פסקה 
Here, it is obvious that Abulafia regards the plain meaning of the Rabbinic discussion as inconceivable and explicitly states the imperative of allegorising it. His observation about the absence of any mention of the serpent's intercourse with Eve shows that he was critical of the mythical element introduced by the Rabbinic mythopoesis. Those statements assembled around one of the most particularist themes in the Rabbinic imaginaire show that Abulafia had dramatically parted ways from the dominant (but not exclusive) Rabbinic point of view on these themes.

Let me put into relief the fact that according to one of the passages quoted above, it is those Rabbis who were interested in popular forms of magic, not the Gentiles, who are described as the people whose pollution did not cease, since according to Abulafia's views, they did not stand on Mount Sinai at all. Such a statement runs sharply against the Rabbinic tradition, which was strongly interested in building the myth of national election, since Abulafia's statement shifts the emphasis from the nation to the individual and from the constitutive moment in the past to the present. Or, to cast this shift in other terms: the mythical events as told in Jewish sources (Rabbinic and then Kabbalistic) that are ethnocentric and thus particularist in so many cases were interpreted by Abulafia in philosophical terms stemming from Greco-Hellenistic sources. This was often done in a careful manner that ought to be decoded by scholars because they constitute the Kabbalist's secret position, which was antithetical to the dominant form of Rabbinic anthropology.

Such an example of antagonism towards a Rabbinic dictum reveals a form of intellectual repulsion towards what Abulafia considered to be a foolish myth accepted by the vast majority of Jewish sources that is, to the best of my knowledge, unparalleled in the Kabbalistic literature of the thirteenth century. Interestingly enough, an inspection of many of the Maimonideans' interpretations of the Paradise myth has not unearthed any critique of the Rabbinic passage about the cessation of pollution. Abulafia's view that the concepts that are found in the minds of all the nations are identical points in the direction of his universalistic view. ${ }^{115}$

זוהמתן. ואיך יקרא חכם שום אדם בעולם ממי שיחשוב שזה הענין הוא כפשוטו ושהנחש הנזכר בתורה בא על חוה והנה התורה לא זכרה אותו.

It should be pointed out that another discussion of this Rabbinic myth is found on the very last page of Mafteah ha-Šemot; unfortunately, the unique manuscript of this commentary is corrupted here. Let me point out that Abulafia's critical approach to the content of the Rabbinic myth separates him from the theosophical Kabbalists' much more positive attitudes towards the Midrash. This separation calls for a qualification of Scholem's view as to the difference between philosophers and Kabbalists in their attitude to Aggadah. See his Major Trends in Jewish Mysticism, 28. As a Kabbalist, Abulafia is a more radical critic of Rabbinic myths than most of the Jewish philosophers.

115 Or ha-Śekhel, 27:

אמנם העניינים הנמצאים בנפש כל האומה ובנפש זולתה בכלל ובפרט הכל יוצאים ממקור אחד. ואפשר לומר עליהם בכלל

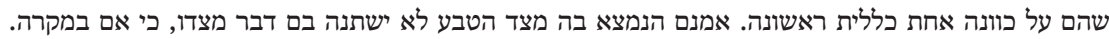

See also my discussion of the context of the parable of the pearl below. The parable is found in Or haShekhel; I will translate it in chapter 12. Compare to the position of Rabbi Levi ben Abraham, as dis- 
In short, Elliot Wolfson's claim that the ontic difference between Jews and Gentiles in Abulafia's thought is grounded in the Rabbinic legend about the pollution and its removal is, scholarly speaking, wrong. It is, to use his terms, "grossly misleading," 116 not only because it ignores the content of Abulafia's hint about the existence of a secret concerning the topic in a passage which Wolfson was acquainted with and quoted, but also, and especially, because he neglects to partake in a serious perusal of Abulafia's literary corpus in order to find parallels that would clarify his meaning. Moreover, this claim of being "misleading" not only inverts the accuracy of my presentation of Wolfson's own view on the topic, but also his view that he has now decided to renege, without admitting it. This earlier approach is part of Wolfson's strong tendency to homogenise Kabbalistic thought in many of his writings as if it was predominantly particularist, and he quite indiscriminately includes Abulafia's writings in this generalisation. An essentialist vision of Kabbalah as a whole fails even on the grounds of the Kabbalistic discussions that are cited for this sake, to say nothing of many other treatments that have been ignored.

I have presented and discussed all the extant passages in order to show a problematic tendency in recent scholarship on Abulafia: scholars writing entire books on quite a specific topic choose to ignore the most relevant treatments and then invert his thought; other scholars read these books and continue to repeat and even amplify those mistakes. If this is the case where scholars of Abulafia are concerned, it is even clearer in cases regarding other scholars who are less acquainted with Hebrew and Kabbalah.

As has been illustrated above, Abulafia's more universal approach, which is quite Maimonidean, by far transcends his unusual and in fact antagonistic interpretation of one Rabbinic legend. The passages I presented earlier in this chapter are by no means exceptional. In the context of surveying Abulafia's different attitude towards Gentiles, let me present his quite explicit declaration that "the eternal life of the soul is the true life, for which all the nations have been created," which makes perfect sense in the context of a universalistic worldview. ${ }^{117}$

cussed by Nachman Falbel, "On a Heretical Argument in Levi ben Abraham ben Chaiim's Critique of Christianity," Proceedings of the Congress of World Union of Jewish Studies 4 (1981): 39.

116 As we shall see below, this is the phrase Wolfson uses in order to refer to my presentation of his view on the topic as well as Abulafia's particularism. See also his "Deceitful Truth and Truthful Deceit: Sod ha-Hippukh and Abulafia's Divergence from Maimonides," in A Tribute to Hannah: Jubilee Book in Honor of Hannah Kasher, eds. Avi Elqayam and Ariel Malachi (Tel Aviv: Idra Press, 2018): $91^{\star}-125^{\star}$ and Appendix E note 219 below.

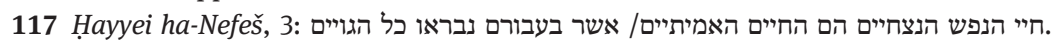

I do not understand why Sagerman (The Serpent Kills, 68) claims that this book evinces a less generous attitude towards the Gentiles. On the basis of this statement, and by assuming that this book was written in 1279 (Sagerman, The Serpent Kills, 45; Hames, Like Angels on Jacob's Ladder, 42), another statement that is far from being a fact (see my "Abraham Abulafia's Works and Doctrine," 11), he introduces psychological speculations as to Abulafia's alleged problems of identity. 
Indeed, all of the Gentile nations (kol ha-goyyim) were created for the sake of the highest religious achievement, as Abulafia envisioned. ${ }^{118}$ This pre-designed vision may have something to do with Averroes's theory of a material intellect that is shared by all mankind. In order to better understand the meaning of the phrase "eternal life of the soul," we may compare it to what Abulafia writes in his Or ha-Śekhel, where he says that the divine speech is the cause of "the union of the soul with her God; this union is the case of the soul's eternal life, similar to the life of her God."119 This means that the highest possible religious attainment imagined by the ecstatic Kabbalist was considered to be open to the Gentiles. This does not mean that he embraced an egalitarian approach to all human beings, ${ }^{120}$ but rather that there is a greater openness in his approach than in any other Kabbalist in the thirteenth century. In any case, he refers to the Gentiles' writings in a positive manner, resorting to the dictum that one should learn the truth from whoever speaks it. ${ }^{121}$ On the other hand, he condemns the multitude and the Rabbis, irrespective of their being Jewish or not.

Extremely important for our point here, and for understanding Abulafia's esotericism, is the manner in which he depicts the special status of the Jewish nation. In his opinion, the Jewish nation is indeed different from the other nations because a greater part of it dedicated itself to study and contemplation compared with other nations. This type of activity was conceived as necessary, hence the large number of students; however, studying is not considered to be an inherently genetic or cor-

His claim there that the book was written as he was on his way to Rome has no support in the material with which I am acquainted. Like Hames, he probably confused this book with Sitrei Torah and then drew conclusions based on this confusion. Also, Sagerman's view in The Serpent Kills, 76, 137, to the effect that Abulafia wrote Sitrei Torah after his attempt to meet the pope, though not entirely impossible, is not supported by any actual evidence in my opinion. For his attitude towards Hayyei haNefeš, see Sagerman, The Serpent Kills, 58. In general, in this book Abulafia is much more critical of the Jewish elite than of Christians. See Hayyei ha-Nefeš, 83, and compare to Sagerman, The Serpent Kills, 92, where the attainment of the world to come is conceived in purely noetic terms.

118 See also one of the verses in the opening poem of Mafteah ha-Ra'ayon, 1:

בו בעלי שכל לכל עם שלחו-תקוה לכל גוים בסוד רבוע.

"He was sent to the masters of intellect in every nation-A hope to all the nations according to the secret of the quarter." See also Hames, Like Angels on Jacob's Ladder, 58.

119 See Or ha-Śekhel, 114: והיא מדבקת את הנפש באלהיה. והדבור ההוא הוא סבת חיי הנפש הנצחיים כחי אלהיה. See also Idel, Studies in Ecstatic Kabbalah, 13.

120 See his Sitrei Torah, 195-96. His attitude towards women was misogynistic. Compare Menachem Kellner, "Philosophical Misogyny in Medieval Jewish Thought: Gersonides vs. Maimonides” [Hebrew], in From Rome to Jerusalem: Joseph Baruch Sermoneta Memorial Volume, ed. Aviezer Ravitzky (Jerusalem: Magnes Press, 1998): 113-28; Abraham Melamed, "Maimonides on Women: Formless Matter or Potential Prophet?" in Perspectives on Jewish Thought and Mysticism, 99-134; and Julia Schwartzmann, "Isaac Arama and His Theory of Two Matches (Zivvugim)," Jewish Studies Quarterly 13, no. 1 (2006): 27-49.

121 See the untitled short treatise found in Ms. Sassoon 290, now Ms. Geneve and Montana, Segre Amar Collection 145, 234. 
poreal quality of the Jews. Even in this case, the Kabbalist is anxious to mention that even in a nation like the Jewish one that is dedicated to studying so that individuals may come closer to God, not all of its members, and perhaps not even its majority, were conceived as being capable of reaching it. He is probably referring here to the Jewish vulgus; nevertheless, the number of individuals devoted to this activity among the Jews is conceived as being greater than that found in other nations. ${ }^{122}$

According to this understanding of the superiority of the Jewish nation, it is no more than a matter of a society's cultural organisation around an intellectual ideal that is considered to be the cause that produces its national specificity in comparison to other nations. This understanding of the Jews' superiority as contemplators reflects the theory of the connection between the human intellect and divine providence which developed among the Maimonideans, especially Samuel and Moses ibn Tibbon, and the version interpreted by two members of the ibn Tibbon family was known, though not accepted, by Abulafia. ${ }^{123}$

In a very fascinating passage, Abulafia, influenced in his tenor by Maimonides's Guide, recommends the recourse to Gentile thinkers in order to prevent the misunderstanding of the plain sense of the Bible:

"He that sits on the circle of the earth,"124 "He that sits in the heavens shall laugh, the Lord shall have them in derision," ${ }^{125}$ and those similar to them should be studied by [means of] the many words of the sages of the world, since by those [forms of] knowledge, the quandaries will be resolved as well as the doubts about many of the imaginative issues, and the man will remain with his intellect in perfection and with his Torah in truth, and the plain senses of the scriptures will not cause his removal from the appropriate path. ${ }^{126}$

122 Mafteah ha-Šemot, Ms. New York, JTS 843, fols. 52b-53a, 26:

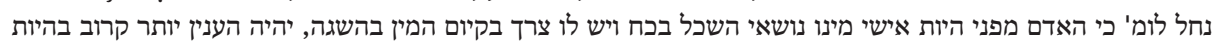

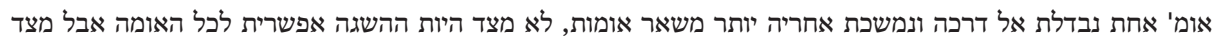

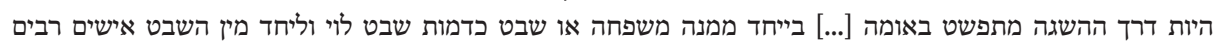
להשגות הקרובות לשם יותר.

"We shall begin to say that a person needs the existence of the species of man in order to comprehend, since the individuals of the species are the portent of the potential intellect. And it is plausible that a certain nation is separated in its path [to comprehension], and it follows this path more than the other nations, not because the comprehension is possible for the entire nation, but because this path is widespread in the nation [...] by their consecrating a family or a tribe like the tribe of Levi and to consecrate individuals of the tribe to comprehensions that are closer of God." Unfortunately, some of the words of this seminal passage are not very clear in the unique manuscript of this commentary. See also the discussion of the nature of the high priest as an intellect that is a direct continuation of this passage in chapter 24 below.

123 See the texts and analyses printed in Diesendruck, "Samuel and Moses ibn Tibbon on Maimonides' Theory of Providence" and The Writings of Rabbi Moses ibn Tibbon, 117, note 324. See also the similar view in Abulafia, Hayyei ha-Nefeš, 142-43; Šomer Mișwah, 12; and Wolfson, Abraham Abulafia, 46-47.

124 Isaiah 40:22.

125 Psalm 2:4.

126 Oșar 'Eden Ganuz, 2:9, 288-89: 
According to Abulafia, when the term "sitting" (yešivah) is related to the supernal world, it actually means existence. In this way, Abulafia also interprets a Rabbinic statement concerning Metatron sitting on high, which he adduced in that context. ${ }^{127}$ To be sure, the Rabbis were also worried about this, since only God was conceived as sitting while the angels were conceived as standing-they were designated as "the standing ones" (ha- 'omedim). This is the reason why they were denied the possibility of sitting, an issue that cannot be elaborated within this framework, but this denial has nothing to do with an anthropomorphic attitude. As to the divine sitting, it was conceived as part of the basilemorphic attributes. The importance of the literal sense of the Seat of Glory is well-known in Rabbinic literature. However, Abulafia understood the term "Seat of Glory" (kisse' ha-kavod) in rather inner-human terms, as we shall see below. ${ }^{128}$

Abulafia was interested in quite a different type of denial. His explicit reference to the "many words of the Gentiles" as presumably capable of saving Jewish authors from an anthropomorphic misunderstanding of the Bible and allowing them to reach a perfect intellect and a true Torah instead of an imaginative one is a phenomenon hardly matched by any explicit formulation I know of from the Jewish Middle Ages, including the writings of the Maimonideans or other medieval Jewish thinkers. The proposal of Gentile thought as a corrective for Jewish misunderstandings of the biblical portrayal of God hardly resonates with a particularist understanding of Abulafia's thought. In any case, according to Abulafia's own testimony, he also tried to reach out to Christians and even praised them for their attitude being more positive towards his messages than that of the Jews. ${ }^{129}$ As discussed above, ${ }^{130}$ Abulafia was ready to discuss matters related to the secrets of the Torah with at least one Christian.

This opening towards the other, based on the viability of a common intellectual enterprise, has no parallel in the various forms of thirteenth-century Kabbalah. We

"היושב על חוג הארץ" (ישעיה מ:כב) "יושב בשמים ישחק אדני ילעג למו" (תהלים ב:ד). וכיוצא באלו הדברים כך ראוי

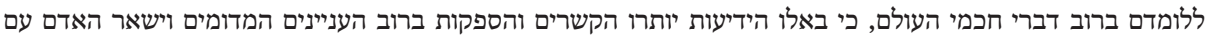

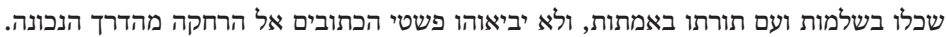
Maimonides's equivocal analyses of the occurrences of the verb YŠV in connection to God, see Guide of the Perplexed, 1:11, Pines, 1:37-38. Maimonides resorted to the two biblical verses mentioned in the two previous footnotes. For a somewhat interesting parallel to the view that philosophy can save one from a misunderstanding of the Bible, see Albalag, Tiqqun ha-De'ot, 83-84. Symptomatically enough, this passage has not been adduced in Wolfson's last attempt at describing Abulafia as particularist, "Deceitful Truth and Truthful Deceit." I hope to elaborate on this seminal passage in a separate study. 127 See BT, Hagigah, fol. 12b.

128 See below chapter 24 note 1.

129 See Sefer ha-Ot, 76; Idel, Kabbalah in Italy, 80; and Wolfson, “Textual Flesh, Incarnation, and the Imaginal Body," 197. Wolfson finds this testimony to be dubious. What cannot be denied, however, is the fact that Abulafia wrote what he wrote and sent it to Spain (or at least intended to), which means that this is the image that he wanted to project, independently of the veracity of the historical fact, in this or in other cases that Wolfson is also inclined to doubt. Abulafia's thought as found in his books is, in any case, independent of what he did or did not do in history.

130 See above chapter 8 note 60 . 
should therefore try to understand who Abulafia's intended audience was. Though writing exclusively in Hebrew, he was nevertheless less concerned with an audience composed of the mythical unit called the nation of Israel. Rather, he was more interested in the intelligentsia within Judaism and, perhaps, outside of it. In this way, Abulafia's approach differs from that of Maimonides.

It is understandable that this shift from a particularist to a more universalist approach is not expressed in an explicit or systematic manner in Abulafia's writings. This reticence and veiled expression is related to the dominance of the mythical register in most of the circles within Judaism, as we can learn from the various phases of the polemics against Maimonides, some of which Abulafia was well-acquainted with, while the more universalist approach may be related to the interregnum period in which Abulafia operated. On the one hand, ibn Adret had already banned Abulafia, ${ }^{131}$ and on the other hand, Rabbi Hillel of Verona, Abulafia's teacher, took the philosophers' side in the second controversy over Maimonides's writings.

In any case, the comparison of Abulafia's radical statements about the "real" nature of the Jews-and, implicitly, of the nations-to those of some philosophers such as the Maimonidean Rabbi David Qimhi and Joseph ibn Kaspi, ${ }^{132}$ to say nothing of some of the theosophical Kabbalists, shows the size of the conceptual gap between

131 See many of the pertinent texts related to the controversies that were assembled and presented by Dinur, A Documentary History of the Jewish People, 139-274; Daniel J. Silver, Maimonidean Criticism and the Maimonidean Controversy: 1180-1240 (Leiden: Brill, 1965); Shatzmiller, "For a Picture of the First Polemic on Maimonides's Writings"; Azriel Shohat, "Concerning the First Controversy on the Writings of Maimonides” [Hebrew], Zion 36 (1971): 27-60; Sarah Stroumsa, The Beginnings of the Maimonidean Controversy in the East: Joseph ibn Simon's Silencing Epistle Concerning the Resurrection of the Dead [Hebrew] (Jerusalem: Ben Tzvi Institute, 1999); Raphael Jospe, Jewish Philosophy in the Middle Ages (Boston: Academic Studies Press, 2009), 551-70; Abraham S. Halkin, "The Ban on the Study of Philosophy" [Hebrew], Peraqim 1 (1967/68): 35-55; Gershom Scholem, Origins of the Kabbalah, trans. Allan Arkush, ed. Raphael Judah Zwi Werblowsky (Princeton: Princeton University Press, 1987), 7-8, 10-12, 337-81; Joseph Dan, “Ashkenazi Hasidim and the Antimaimonidean Controversy," Maimonidean Studies 3 (1995): 29-47; Charles Touati, "Les deux conflits autour de Maïmonide et des études philosophiques," in Juifs et Judaïsme de Languedoc, eds. Marie-Humbert Vicaire and Bernard Blumenkranz (Toulouse: Edouard Privat, 1977), 173-84; Gregg Stern, "Philosophical Allegory in Medieval Jewish Culture: The Crisis in Languedoc (1304-1306)," in Interpretation and Allegory, ed. Jon Whitman (Leiden: Brill, 2002): 189-209; Schwartz, Contradiction and Concealment in Medieval Jewish Thought, 112-43; Dov Schwartz, "Changing Fronts in the Controversies over Philosophy in Medieval Spain and Provence,” JJTP 7 (1997): 61-82; Ram Ben-Shalom, “Communication and Propaganda Between Provence and Spain: The Controversy Over Extreme Allegorization (1303-1306)," in Communication in the Jewish Diaspora: The Pre-Modern World, ed. Sophia Menache (Leiden: Brill, 1996), 171225; Ben-Shalom, The Jews of Provence and Languedoc, 461-62, 511-64; Ram Ben-Shalom, "The Ban Placed by the Community of Barcelona on the Study of Philosophy and Allegorical Preaching-A New Study,” REJ 159 (2000): 387-404; Saperstein, Decoding the Rabbis; and, last but not least, Halbertal, Between Torah and Wisdom, 152-79.

132 See the passages assembled by Dinur, A Documentary History of the Jewish People, 303-15. 
their position and Abulafia's own much more universalist position. ${ }^{133}$ This is the meaning of "radical" in the specific historical context we have discussed here: the antithetical attitude found in many of the traditional Jewish sources is here turned towards the vulgus rather than towards the Gentiles.

It suffices to mention in this context Abulafia's rather astonishing definition of what a Jew is: someone who confesses the name of God that explicitly occurs in at least two of his prophetic writings. ${ }^{134}$ This is an exceptional position in the Middle Ages and should be seriously taken into account before one decides that Abulafia was a particularist Kabbalist. In my opinion, we have here one of the most audacious attempts at an open reform of Rabbinic Judaism by proposing the search for ecstasy by means of divine names as an ideal and even the most important criterion for Jewishness.

In short, one should not take the fact that Abulafia quoted biblical and Rabbinic material as meaning that he adopted the worldviews found in those Jewish sources, just as it would not be wise to do so in the case of Maimonides, upon whose views Abulafia draws in this specific case, though he dares to explicate much more than the Great Eagle did. Quotations from traditional sources should be understood in their fuller context and not as self-evident vehicles for conveying the intentions of their ancient authors.

Nor does Leo Strauss's warning, according to which the fact that someone repeats a certain idea does not mean that this idea is a hidden view, ${ }^{135}$ hold in our case, given the fact that Abulafia openly contradicts the traditional Rabbinic anthropology. This contradiction is emblematic and the persecutions he claims to have suffered from are reminiscent of one of the few other Jewish thinkers who were officially banned, Baruch Spinoza. Both thinkers share a kind of pantheistic approach and critique major aspects of Rabbinic Judaism; both are, in their distinct ways, descendants of Maimonides's thought, though Spinoza was far more critical of the Great Eagle and incomparably more analytical and systematic in his geometrical expositions of his metaphysical alternative than anything that can be found in Abulafia's writings. ${ }^{136}$ Nevertheless, Abulafia's critique is based on a fundamental topic of

133 Abulafia was well-acquainted with some of the critiques of Maimonides, as we can see from his two commentaries on the secrets in the Guide. For example, see Hayyei ha-Nefeš, Ms. Munich, 408, fol. 47a, 81. For Maimonides's universalistic propensity, see Kellner, Maimonides' Confrontation with Mysticism.

134 See Moshe Idel, “A Unique Manuscript of an Untitled Treatise of Abraham Abulafia in Biblioteca Laurentiana Medicea,” Kabbalah 17 (2008): 20-23.

135 Persecution and the Art of Writing, 30-31.

136 Strauss, Spinoza's Critique of Religion; the collection of translated articles in Leo Strauss, Le testament de Spinoza: écrits de Leo Strauss sur Spinoza et le judaïsme, eds. Gérard Almaleh, Albert Baraquin, and Mireille Depadt-Ejchenbaum (Paris: Cerf, 1991); Franz Nauen, "Hermann Cohen's Perceptions of Spinoza: A Reappraisal,” AJS Review 4 (1979): 111-24. For a survey of the affinities between Abulafia and Spinoza in my various studies, to be understood as related to sources influenced by 
human nature and society: the negative role played by imagination. Although it plays an important role in political organisation, it obstructs perfect cognition.

Given the fact that Abulafia addressed the Rabbinic discussion of the serpentine pollution more than any other Kabbalist (with the exception of the contemporary vast corpus known as the book of the Zohar, which took this Rabbinic statement quite verbatim), and given the fair number of passages dealing with this issue in his writings, our survey above has to reflect not only on the understanding of his thought as more universalistic, in the line of Maimonides, but also on the nature of his Kabbalah as a whole. Given the rather scant occurrences of the Rabbinic discussion in other Kabbalistic writings or the theosophical-theurgical schools, to take Wolfson's survey in his Venturing Beyond as representative of what is found in this vast literature, a broader question looms. Abulafia has been misrepresented as a particularist due to scholars ignoring his immense formative debt to the thought of Maimonides and that of Arabic philosophers. His view on the topic under scrutiny here, dealing with the Gentiles, has also been presented in an inaccurate manner. These two misrepresentations are related to the general incorrect scholarly attitude that Kabbalah is homogeneous on this specific point.

Moreover, insofar as I am acquainted with the Maimonidean literature, it seems that Abulafia was the first author to explicitly allegorise this specific Rabbinic statement as pointing to an atemporal situation. Indubitably, given a choice between the particularist views found in most of the Rabbis, mythical (especially Zoharic) Kabbalists, and Rabbi Judah ha-Levi's Kuzari on the one hand and the universalist approach of the Great Eagle on the other, Abulafia would definitely have chosen the latter as the source of authoritative guidelines on this topic.

Abulafia's failure to mention Judah ha-Levi's book in the series of writings he studied, or to mention him at all in those writings, is, in my opinion, not a matter of ignorance or neglect, but a rejection that is part of a wider phenomenological bifurcation that is seen in the thought of the theosophical-theurgical Kabbalists as being significantly informed by the Kuzari. Again, Abulafia drew his inspiration mainly from Maimonides's thought and that of the Muslim falāsifah. This does not mean that he was not acquainted at all with ha-Levi's book, but rather that he did not agree with its basic approach and did not consider it worthy of criticism.

All this being said, I would not be surprised if someone was able to find another attitude towards the Rabbinic discussion that would fit the interpretation of Abulafia's thought as particularist in one of Abulafia's books with which I am not yet acquainted. As part of the conceptual fluidity I mentioned above, I propose not to reify a person's thought as if it were constituted of frozen entities, but to allow, at least in principle, the possibility of the existence of diverging or even opposing positions that would confirm the particularist interpretation, like Sefer ha-Melammed, p. 32.

Abulafia and plausibly known to Spinoza as they were found in print, see the summary in Harvey, “Idel on Spinoza," 99-105, and my Messianic Mystics, 79-82. See also chapter 16 note 98 below. 
However, this latter position would have to be illustrated by examples that I have not found in the extant sources. For the time being, however, Abulafia's relatively universal position as reflected in his interpretations of the Rabbinic view is quite evident, and I doubt whether it is possible to find material dealing with this precise topic that endorses a different interpretation of the above passages that could challenge this evaluation of Abulafia's universalist position.

Indeed, the above considerations as to the importance of political esotericism as an essential aspect of Abulafia's thought invite a more careful reading of many of his statements, especially when these statements contradict each other, or, even more significantly, when they contradict common wisdom in traditional Judaism. Indeed, if two different statements may be discerned, one which contradicts the accepted views on Judaism and another which confirms the regular themes, we should not dismiss the divergent views. This is not to say, however, that all the instances of the terms sod or seter in Abulafia's writings stand for a sort of political esotericism, as other types of esoteric issues exist in his works, as has been pointed out above. Without the necessary awareness of the existence of an esoteric level, one may indiscriminately confuse Abulafia's exoteric and esoteric registers.

\section{The Torah as a Median Entity}

Let me turn now to another esoteric topic that touches a very sensitive chord within traditional Judaism and Maimonides's thought: the nature of the Torah. As in the case concerning the removal of the serpentine pollution, Abulafia's opinion can be quite easily understood if we take into consideration the several discussions of this topic he gives in his various books. However, given that the issue of the Torah is much more sensitive, I would like to illustrate Abulafia's treatment of the topic of the Torah with the earliest instance found in the starting point in his literary career. In his first extant book, Get ha-Šemot, which he wrote in 1271, Abulafia makes several references to secrets that he does not reveal. ${ }^{137}$ This means that the politics of esotericism that he adopted in his first Kabbalistic book was not necessarily a new starting point in his way of thought, but in my opinion, it is quite plausible to assume that it reflects an earlier, philosophical period in his intellectual development.

In this book, Abulafia describes the two major techniques for eliciting the secrets of the Torah as consisting of the linguistic techniques of Sefer Yeșirah and the philosophical exegetical techniques of distinctions between different meanings of biblical nouns, the homonymies, which is characteristic of the method of The Guide of the Perplexed. These distinctions can also be found in some of his other writings that

137 Geț ha-Šemot, 2, 3, 30, 31, 32, 34, 35, 40. See also his early book, Mafteaḥ ha-Ra'ayon, 23, where he mentions the oral transmission of secrets. 
deal with logic, which were discussed in chapter 6 above. ${ }^{138}$ This combination of entirely different types of exegesis into a sevenfold structure sets the tone for all of his later writings. In a more minor manner, this combination is also found in the work of his teacher, Baruch Togarmi, as linguistic methods and modest philosophical terminology of a Neo-Aristotelian nature occur together in Togarmi's Commentary on Sefer Yeșirah.

I shall start by decoding the meaning of a discussion that is not explicitly designated as a secret. After describing the fact that the personal names in the Bible can be explained as having meaning, a view that is part of his divorce from meaningless magical names (to which the title of the book refers), Abulafia writes:

I had already mentioned to you the truth existence and the intellectual one in general, and about the nature of man, the external and the internal, and about the paths of prophecy, the plain sense and the hidden one, that depend on letters, words, and numerical calculation, in order to announce to you their subject matter from all aspects. And behold, the Torah is the middle [emșa it $]$, ${ }^{139}$ the tree of life, as it is written ${ }^{140}$ "and the tree of life in the middle of the garden, and the tree of knowledge of good and evil." ${ }^{{ }^{141}}$

That a secret is hinted at here is obvious from the resort to the assumption of a hidden sense that depends on the exegetical methods the Kabbalist uses. The Torah is described using the Hebrew word emsa it ("the middle"), which has the same value in gematria as the consonants of "Torah" (TWRH), 611. To be sure, though this gematria is not hinted at here, this is certainly not my finding, since it recurs in Abulafia's later writings in several instances. This description can be seen as part of the widespread affinity between the Torah and the tree of life which is found in Rabbinic Judaism.

Neither the implicit gematria nor the identification with the tree of life is to be considered as esoteric. However, this median status should be understood in the fuller context of the above passage. Immediately before the discussion of the Torah, Abulafia mentions several pairs: sense versus intellect; the plain sense versus the hidden one; and external/internal man and the two trees in Paradise. The Torah should be understood as a sequel of these pairs; namely, as standing between pairs of two extremes. This means that it has a sensual and an intellectual dimension, the plain sense and the hidden sense; it belongs to both the external and inter-

138 Geț ha-Šemot, 5-6.

139 The biblical תוך, which means "within the Garden," was interpreted in several cases before Abulafia as "in the middle of the Garden."

140 Genesis 2:9.

141 Geț ha-Šemot, 40:

וכבר העירותיך על אמיתת מציאות המורגש והמושכל בכללו, ועל טבע האדם החיצון והפנימי, ועל דרכי הנבואה הנגלים

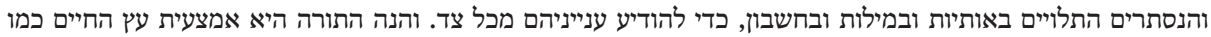


nal natures of men. In this context, it is plausible that it also stands between the tree of life and the tree of the knowledge of good and evil.

The question is, what does such an interpretation mean? This is not explicated in Geț ha-Šemot, but it is elaborated further in a parallel passage found in Or ha-Śekhel, part of which will also be dealt with in Appendix C:

There are two attributes, truth and fear; the former comprises the knowledge of God that is the knowledge of truth, and the latter comprises the fear of God that is the attribute of fear. And behold, after you conceptualise the two extremities mentioned insofar as faith is concerned, which are not dependent on deeds, you should conceptualise that the Torah is the median [emșa $i t]^{142}$ between the two, just as the study of the Torah announced to you the path of the appropriate deeds that you should walk on, and the path of the inappropriate ones that you should stray away from. And provided that all the commandments are following faith, they amount in gematria ${ }^{143}$ to the knowledge of God. ${ }^{144}$

The gematria of 611 is again implied, but not explicated. The Torah is once more mentioned after a series of pairs: the two attributes of truth and fear and knowledge of God and fear of God. It is plausible that the attribute of truth corresponds to the intellectual sense in the passage from Get ha-Šemot, and, by default, the attribute of fear to that of the sensual realm. As Warren Zev Harvey pointed out to me, these pairs correspond to the first two commandments, reducing the 613 ones to 611, and those 611 commandments are described as the middle.

However, in this passage, the terminology points in an obvious manner to theosophical imagery, especially when the attribute of fear, expressed by the Hebrew Pahad, is used. In the common theosophical scheme, the attribute of Pahad is

142 See also a very similar discussion in Rabbi Nathan's book, Le Porte della Giustizia, 462, where the emșa'it referring to the third attribute is again depicted between two divine attributes in the context of the occurrence of the form תורה. However, it is possible that this form may be understood as toreh; that is, as referring to the third and not the Torah. For emșa'i as a reference to the imaginative faculty, see Maimonides's Guide of the Perplexed, 2:45.

143 This is a widespread calculation of the number of the commandments (613) from the numerical valences of words in Exodus 3:15 mentioning the divine name (šemi), the remembrance of God (zikhri), and the letters of the divine name, as Abulafia mentions immediately afterwards on the same page.

144 Or ha-Śekhel, 20:

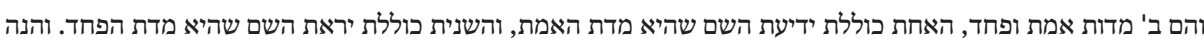

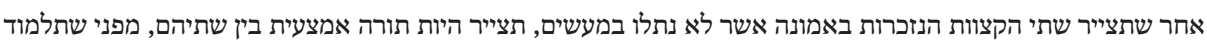

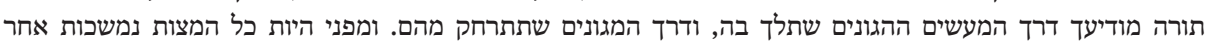
האמונה, עלו כן במספר שווה לידיעת השם.

On the possible relation of the median role of the Torah and the Aristotelian and Maimonidean concept of the Golden Mean, see my Language, Torah, and Hermeneutics, 165, note 47. For this theory in general, see Marvin Fox, "The Doctrine of the Mean in Aristotle and Maimonides: A Comparative Study," in Studies in Religious and Intellectual History Presented to Alexander Altmann on the Occasion of His 70th Birthday, eds. Siegfried Stein and Raphael Loewe (Tuscaloosa: University of Alabama Press, 1979), 98-120, reprinted in his Interpreting Maimonides, 93-123, and Herbert A. Davidson, “The Middle Way in Maimonides's Ethics,” PAAJR 54 (1987): 31-72. 
found on the left side, while that of truth (Emet) is found in the middle between two "higher" attributes. Emet corresponds to Jacob just as Pahad corresponds to Isaac, as is mentioned in the passage above. However, it is obvious that the attribute of truth is conceptualised as the opposite of fear and thus it is found on the right side, while the Torah stands in the middle, between the two "higher" attributes. This is an uncommon type of symbolism, as we shall see in more detail in Appendix $\mathrm{C}$ below.

This understanding of the Torah as the median may also reflect a theosophical view that identified the Torah with the sefirah of Tif'eret that stands in the middle of the two other divine powers. This seems to be the meaning of the median place of the Torah here. Interestingly enough, truth and fear are not conceived as being conducive to deeds, which is a quality reserved solely for the Torah.

What is shared by the last two quotes is the common status of the Torah as a median entity, which is expressed using different forms of imagery, both philosophical and theosophical. An important question that should be asked in this context is what do we understand from Abulafia's use of theosophical imagery: is there a structural homology between the triad of divine attributes and human feelings, meaning that Abulafia believed in the first triad as a blueprint for the second, human triad within the lower world? Alternatively, does the Kabbalist allegorically interpret what he conceives to be an imaginaire found in a theosophical literature whose conceptual basis he did not accept? The fact that his main concern was the median place of the Torah is illustrated by a variety of examples from other realms: the two trees in Paradise, the intellectual and the sensual, and the knowledge of God (which also means the love of God) and the fear of God (which implicitly does not assume knowledge).

One might read the homologies as having some form of sympathetic affinity between the distinct pairs of entities mentioned above, affinities that would include both a theosophical and a potentially theurgical valence-in a manner reminiscent of Mircea Eliade's magical universe ${ }^{145}$-while another scholar might see the homology as merely rhetorical or analogous structures and assume the existence of one basic pair found within the human being. This bipolar human structure constitutes the basis of the allegorisation of the meaning of the other pairs, some of them of a cosmic nature. The parallelism between different triads does not, according to such a

145 See Mircea Eliade, "The Cosmical Homology and Yoga," Journal of the Indian Society of Oriental Art 5 (1937): 188-203. Nor do I believe that for Abulafia, the noetic awakening of the individual has an effect on the external universe in the manner Eliade describes as the meaning of the principle of homology in some yoga practices in his Yoga: Immortality and Freedom, trans. Willard R. Trask, 2nd ed. (Princeton: Princeton University Press, 1970), 108, 251-52, 254-55, 341. See also Idel, Mircea Eliade: From Magic to Myth, 4-14. For Abulafia's view of the prophet as changing the course of nature by means of divine names, but not as part of the principle of homology, see chapter 17 below. 
reading, mean that there is a sympathetic or theurgical affinity between them, which we may learn from a lengthy passage from Oșar 'Eden Ganuz. ${ }^{146}$

I propose to adopt the second interpretation because Abulafia repeatedly speaks about the need to free the intellectual element from the material realm, this being one of the targets of his techniques. Abulafia does not inhabit a harmonious universe, but rather one based on a deep dualism that distinguishes between the intellect on the one hand and matter, imagination, and desires on the other, a disjunctive approach that we discussed in the previous chapter concerning his anthropology. This is the reason why he is less interested in learning about the divinity from the divine acts or natural phenomena, as philosophers do. He prefers to learn about the divinity from divine names. ${ }^{147}$ To be sure, Abulafia utilises more of a Platonic type of dualism than a Gnostic one.

This second reading means that for Abulafia, it would be a misunderstanding to take the imagery of the divine attributes literally, since, as he puts it, God has no attributes and what we do attribute to Him is solely a human exercise intended to understand Him by means of our categories. ${ }^{148}$ According to another statement, probably stemming from Ismāīlite sources, though also found among other Kabbalists in Abulafia's generation, ${ }^{149}$ God cannot be described as a being or even as a nonbeing. ${ }^{150}$ In our context, the dyadic opposition of attributes is important not for conveying his theosophy, but for understanding the Torah's special status standing in the middle.

According to an additional source, the Torah is conceived as a median between God and man, another instance of mediation. ${ }^{151}$ However, what is crucial in the Torah occupying a median position is explicated in another passage from the same book, where the approach in the last two passages finds an explanation. There, the ecstatic Kabbalist distinguishes between three types of apprehensions: "Each true human apprehension in general is either close to the intellect, as an intellectual one, or remote from it, as the sensual one [is], or the median one [emșa it], which is between them, as imaginative, all [of them] coming from God, blessed be He." ${ }^{152}$ The vision of the

146 See 199-200, translated in Wolfson, Venturing Beyond, 71-72. On causal versus non-causal correspondences, see Hanegraaff, Esotericism and the Academy, 181, note 110.

147 See Or ha-Śekhel, 108-9, and "Ševa' Netivot ha-Torah."

148 See Šomer Mișwah, 42. On this issue, see more my detailed discussions in Middot, chapter 9. 149 See Idel, Old Worlds, New Mirrors, 163, 288, note 22.

150 Ms. Oxford, Bodleian 2047, fol. 68b. For another quote from this anonymous text, see chapter 10 above as well as Wolfson, Abraham Abulafia, 161, note 182.

151 Sefer Gan Na'ul, 2.

152 Šomer Mișwah, 118:

שכל השגה אמיתית אנושית בכלל בין קרובה לשכל כמושכלת בין רחוקה ממנו כמורגשת, בין האמצעית אשר ביניהם כמדומה, כולן באות מהשם יתברך.

This passage parallels Aristotelian noetics and is also found in Rabbi Hillel of Verona, Tagmulei haNefeš, 73-100. There are many discussions in Abulafia about the median status of imagination as a faculty that stands between two other modes of cognition. Only a few will be discussed below. See 
median apprehension as imaginative is not directly related to the Torah, but given the content of the passage from Get ha-Šemot, where the sensual and the intellectual existence are mentioned in the context of the Torah, this oblique reading of the two sources as corroborating each other seems to be more than plausible. This means that the Torah is understood as mediating and thus as standing in the middle between the intellectual and the sensual, just as the imaginative power does. This median status of the imaginative power is also found in a poem attributed to a certain “Abraham KNT (קנת)," which I take to be some form of distortion of Abulafia's name, extant in one manuscript. In the poem, the author says that "the imaginative is the median [emșa $i]^{\prime 153}$ in a context that mentions both the sensual and intellectual types of cognition.

In a memorable passage from Or ha-Śekhel, where he allegorises some biblical verses, Abulafia offers a threefold categorisation of the activity of the imaginative faculty:

But imagination never attains true existence, ${ }^{154}$ but it is "a strong ass couching down between the sheepfolds." ${ }^{155}$ Sometimes it tends to the sensible and keeps its existence as the senses com-

also his Imrei Šefer, 16; Mafteah ha-Sefirot, 14; and Mafteah ha-Tokhahot, 23. For the assumption that a
discussion about the correspondence between philosophy and religion is compounded and median,
see Eisenmann, Moshe b. Judah: Ahava ba-Ta'anugim, 171-73, where Averroes's impact is quite explic-
it

153 Ms. Vatican, 441, fol. 92a:

אם למורגש נ[י[תן מאות|למושכל נ[י[תן רבבות| אך המדומה הוא אמצעי| כחו נוטה לשתי פאות| אם למורגש יטה הרבה| כזב בתמונות לו באות| או אם למושכל למשל הוא נוטה| ורב לו חכמות ונבואות.

There is additional Abulafian material in this manuscript. See Moshe Idel, "Sefirot above Sefirot" [Hebrew], Tarbiz 51 (1982): 260, and Idel, Kabbalah in Italy, 144; 388, note 23; 389, notes 38 and 40. More Abulafian material can be found in this manuscript (fol. 115a), as I shall show in a separate study in which I hope to print and discuss the entire poem.

154 Compare to the sharp distinction between intellectual and imaginative comprehension in Hayyei ha-Nefeš, 144-45, 160, and the anonymous Sefer Toledot Adam, Ms. Oxford, Bodleian 836, fols. 171b172a, where the affinity between imagination and doubt is explicit, perhaps an impact of Abulafia's Sitrei Torah, 152. Let me point out that in my opinion, imagination is conceived as a hindrance to achieving the ideal type of cognition promoted in Abulafia's ecstatic Kabbalah, and only rarely so in theosophical Kabbalah. For an alternative view, see Wolfson, Through a Speculum That Shines and Wolfson, Language, Eros, Being, especially 3. This latter issue deserves a separate analysis that transcends the present framework. In short, my claim is that when the Kabbalists speak about imagining or visualising, they use precise terms, which I have written about elsewhere, and when they do not intend such processes, there is no need to impose a general assumption on such practices by means of oblique interpretations that mingle together material from different Kabbalistic schools. See my Kabbalah: New Perspectives, 103-11; Studies in Ecstatic Kabbalah, 73-89; Enchanted Chains, 228-32; Golem, 119-26; "Kabbalistic Prayer and Colors," in Approaches to Judaism in Medieval Times, vol. 3, ed. David R. Blumenthal (Atlanta: Scholars Press, 1988): 17-27; and "Kawwanah and Colors: A Neglected Kabbalistic Responsum" [Hebrew], in Tribute to Sara: Studies in Jewish Philosophy and Kabbalah Presented to Professor Sara O. Heller Wilensky, eds. Moshe Idel, Devorah Dimant, and Shalom Rosenberg (Jerusalem: Magnes Press, 1994): 1-14. Rather than entities to be imagined or visualised, the sefirot were 
prehend it, other times it tends to the intelligibilia and keeps its existence as [long as] the intellect comprehends it, and sometimes it invents everything from its heart and there is no reality to it at all, despite the fact that it thinks that whatever it comprehended is solely the truth, and nothing else is [the truth]. And this third imaginative apprehension leads every true existing apprehension to error and confusion, and always denies it. When the memory of the abovementioned imaginative false apprehension is effaced from the hearts of [those who] sense and the intellectuals, "death will be destroyed forever and God will wipe away tears from all faces, he shall remove the insult of his people from the whole of the earth"; ${ }^{156}$ namely, [the verse points to] the secret of the intellect being revealed after it was hidden. ${ }^{157}$

The passage refers to a standard Aristotelian type of noetics. The statement found in the opening sentence is crucial: imagination, referenced in general terms, does not allow for a comprehension of reality. It can indeed serve both the senses and the intellect, as in the verse of the poem mentioned above. It can also sometimes run wild. In any case, by itself it is not reliable from the cognitive point of view. According to another of Abulafia's statements, the effacement of the imagination is conceived as possible and even necessary for the emergence of the intellect. In a later treatise, he speaks about the possibility of killing the imagination. ${ }^{158}$ Elsewhere, he speaks about imagination as a natural, innate faculty that cannot be changed. ${ }^{159}$

However, I would opt for the assumption that the theme of the ass has something to do with the burden of the commandments, as Abulafia explicates elsewhere in an-

categories considered to be capable of mapping and interpreting the canonical texts in a new manner or influencing the divine powers by means of the performance of the commandments. See, especially, Idel, Absorbing Perfections, 280-95. See also Appendix B note 96 below.

155 Genesis 49:14. See also Idel, Studies in Ecstatic Kabbalah, 59, 76. The consonants of Hamor (ass) are the same as those of Homer (matter). In his Or ha-Śekhel, Abulafia connects imagination to the compounded entities; see chapter 2 note 76 above.

156 Isaiah 25:8.

157 Or ha-Śekhel, 119:

והדמיון אינו משיג שום מציאות אמיתי לעולם, אבל הוא "חמור גרם רבץ בין המשפתים" (בראשית מט:יד), פעם נוטה

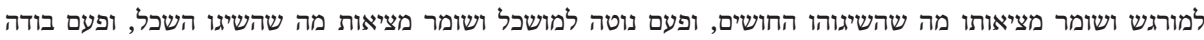

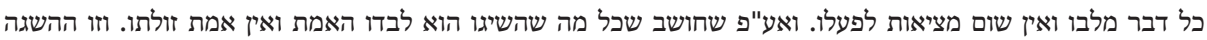

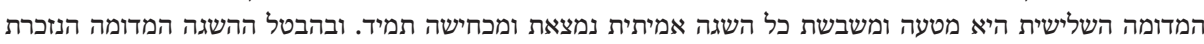

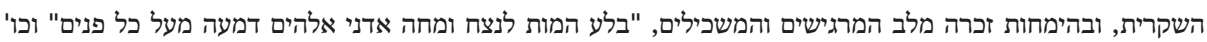

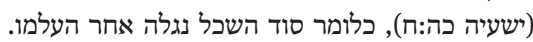

See also Idel, The Mystical Experience, 99-100, 132, 144, 172, note 285; Idel, Studies in Ecstatic Kabbalah, 66, 69, note 9; Idel, "Types of Redemptive Activities," 260-61; and Idel, “Abraham Abulafia: A Kabbalist 'Son of God,"” 80-81. This passage was copied verbatim almost in its entirety without reference to the source in the anonymous Sefer Toledot Adam, Ms. Oxford, Bodleian 836, fol. 159a, a book that has been referenced several times above. For another example of this author copying from another of Abulafia's books, see Idel, The Mystical Experience, 200-201.

158 Sefer Gan Na'ul, 58-59. See also Idel, The Mystical Experience, 132. I hope to return to this theme and its possible sources in a separate study.

159 Hayyei ha-Nefeš, 156-57. For a view of dimyon as phantasy, see Abulafia's Mafteah ha-Ra'ayon, 24. 
other of his writings. ${ }^{160}$ A rather explicit connection between the imagination and the commandments is found in his Mafteah ha-Ra'ayon and his Or ha-Śekhel. ${ }^{161}$ I wonder whether this is not also a reference in the historical register to Christianity conceived as imagination, which is to be understood not only as a historical phenomenon, but also allegorically, as a component of every person's spiritual structure when they are unredeemed, including Abulafia. ${ }^{162}$

Abulafia, in what I consider to be a seminal passage, understands imagination as a median and as being much more "demonic" than in the earlier passages discussed in this chapter. In this text, for the first time, Abulafia says that this is an important esoteric matter:

Now I shall reveal to you this wondrous secret, hidden from the eyes of most of the sages of this generation, and I would say almost from the eyes of all [of them], despite the strength of its visibility. And its rank will be considered high, and the intensity of the delight of its knowledge to those who are acquainted with it, and the power of the delight of its comprehension to its inquirers. This is because the imaginative faculty is the tool for the apprehension of prophecy and all of its apprehensions are imaginative and parables and enigmas. And this is a faculty that is found in most of the animals and in every living being that possesses a heart. And its existence in man is similar to the existence of prophecy in a mirror or in water, and this is a bloody ${ }^{163}$ conceptualisation. ${ }^{164}$ And just as its name is, so it is imagination [dimyon], imagining, and its secret is demon and it is a demon and a Satan, and indeed medion-namely, a median [emșa $\left.{ }^{i} i\right]-$ and all of its strategies are political [mediniyyot $] .{ }^{165}$

This is a rare example of exegetical ingenuity that resorts to the permutation of the consonants of the Hebrew term for "imagination" (DMYWN), which generates MDYWN (Medion, median), and DYMWN (Demon, demon), as well as the Hebrew

160 See the English translation and analysis of this text in Idel, Language, Torah, and Hermeneutics, 59.

161 On this issue, see Idel, Language, Torah, and Hermeneutics, 57, and Idel, "The Battle of the Urges: Psychomachia in the Prophetic Kabbalah of Abraham Abulafia.” The passage from Mafteah ha-Ra'ayon, 69, is especially important and deserves a separate analysis.

162 See Idel, “Abraham Abulafia: A Kabbalist 'Son of God,” 78-83.

163 In Hebrew, דמיי contains some of the consonants of דמיון. As Warren Zev Harvey pointed out to me, דמיי" here may perhaps mean "sanguine" in the technical sense of the theory of humours (ליחות); i.e., having a predominance of red bile or blood and therefore being predisposed to happiness, courage, hope, and love.

164 I assume that prophecy is envisaged here as some form simulacrum of the reality that is more original on another level.

165 Oșar 'Eden Ganuz, 1:3, 121-22:

עתה אגלה לך זה הסוד המופלא הנעלם מעיני רוב חכמי דורינו זה וכמעט אומר מעיני כולם, עם חוזק הראותו ותיקר מעלתו

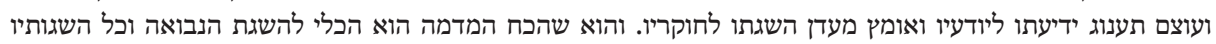

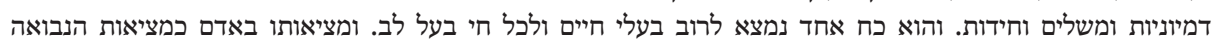

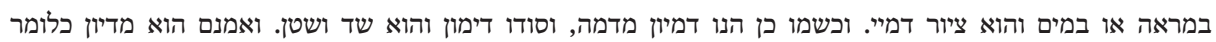
אמצעי. וכל תחבולותיו כולם מדיניות.

For a translation of the fuller context of this passage, see Idel, Language, Torah, and Hermeneutics, 56-57, and Wolfson, Language, Eros, Being, 242. 
term for "political" (MDNYWT, Mediniyyot). This is a nice and concise summary of a radical interpretation of Maimonides's esotericism: prophecy is dealing with a combination of intellectual and imaginative topics, and this is the reason why it contains so-called demonic and imaginary aspects that are political devices. They are instruments, intermediaries, playing as they do a median role.

Though the Torah was not mentioned here, it is well-represented by the hint about the median and in the mention of prophecy. To put it more generally, in addition to the conceptual radicalism as to the nature of the Torah, there is also an exegetical radicalism consisting in the possibility of manipulating the canonical texts using many numerical and combinatory techniques. All of these are accompanied by the eschatological radicalism of a person who assumes that some form of redemption is at hand. Therefore, this is the appropriate time to reveal secrets. His exegetical radicalism may well be one of the reasons why he did not resort to ibn Ezra's critique of the authorship of a part of the Pentateuch: for Abulafia, the entire text was a prime matter for permutations and allegorisations.

Let me address Abulafia's use of the word “demon.” By using a Greek term, he refers to an evil power that does not, in his view, possess an ontological status, which means that unlike most of the other Kabbalists, he does not believe in a quasi-independent system of evil powers, which emerged in some Castilian forms of Kabbalah during his lifetime. Following Maimonides, the scene of the spiritual life is now the human soul, and thus it has a purely cognitive valence, which should avoid the activity of imagination. ${ }^{166}$ This is a major difference between him and other Kabbalists, since in the case of the theosophical-theurgical Kabbalists, the existence of the "externals" (ha-hisononiyyim), a widespread term for the demonic powers, parallels, sometimes inversely, the system of good powers. This double system is also used in order to drastically distinguish between the Jews and the Gentiles. ${ }^{167}$ The absence of a theory of ontological evil in Abulafia is reminiscent of the marginal role played by the ontological status of the theosophical powers, known as the divine sefirot, in his writings. ${ }^{168}$

166 For the power of imagination in Maimonides's thought, see Stern's many discussions in his The Matter and Form of Maimonides's Guide, especially 5, 122-23, 177-81, and especially the Guide 1:73, Pines 1:209-10, where imagination is described as contrary to intellection.

167 Demonological systems also attract the demonisation of the other. See the many examples I present in "The Attitude to Christianity in Sefer ha-Meshiv," Immanuel 12 (1981): 77-95, as well as in Wolfson, Venturing Beyond.

168 Compare my view of Abulafia's understanding of demons as purely imaginary, to Sagerman's quite different, somehow ontological portrayal of Abulafia's demons, that is reminiscent to the writer of views in the Zohar. See his The Serpent Kills, 153-54, 158-59. I am not confident that Sagerman was always aware of the purely imaginary nature of evil in Abulafia's thought. See Sagerman, The Serpent Kills, 138. See also, e.g., Abulafia's Hayyei ha-Nefeš, 89, 90, Oșar 'Eden Ganuz, 56, 96, 118, 121, translated above, or Mafteah ha-Šemot, 16. This topic will be treated in a separate study on the basis of additional sources. 
The view that the Torah includes both intellectual and sensual matters at the same time as being imaginative is found in a longer series of Abulafian texts. ${ }^{169} \mathrm{Abu}$ lafia's view differs from Maimonides's explicit and well-known thesis that Moses's prophecy was distinguished from that of the other prophets because he did not use his imaginative faculty. Whether this was indeed Maimonides's ultimate view is, however, far from being clear. Of course, it may well be part of the hidden teaching of the Great Eagle. However, it may also be that he believed that the Torah had an imaginative aspect and that such a view was part of his esoteric position. ${ }^{170}$

Abulafia's emphasis on the importance of this secret at the beginning of the last quote is hardly matched by anything else in his writings. Indeed, it must touch on a major religious topic. This emphasis on the esoteric nature of the discussion requires closer attention to be paid to the implications of that secret, and I am convinced that what Abulafia wanted to hide was the imaginative nature of the Torah, or at least its possession of such a dimension in a significant manner. In my opinion, this is not just a major topic that stands alone, but rather its meaning radiates onto a variety of other important topics, such as the status of the commandments within the elitist type of religion Abulafia was attempting to esoterically propagate in his writings.

By attributing an imaginative dimension to the Torah, Abulafia mitigates the stark opposition between the founding document of classical forms of Judaism and all the other religions, a distinction that Maimonides attempted to present, in my opinion, as his exoteric position. Implicitly, Abulafia's view is a more universal approach, though it does not gravitate around the centrality of intellectual activity. This significant insertion of the imaginative power as a decisive factor, although not the only one, into the inner structure of the founding document of Judaism has parallels among the Maimonideans with whom I am acquainted, culminating in Spinoza's approach to the Hebrew Bible as being solely related to instructions that only held for specific historical circumstances that were politically, though not philosophically, significant. ${ }^{171}$

Returning to the first passage from Get ha-Šemot presented in this chapter, I believe that the later elaborations we have provided here do not add much to an attentive reading of the early discussion. The great secret divulged in a more elaborated manner in Oșar 'Eden Ganuz, 1:3 is, in my opinion, already contained in nuce in Get ha-Šemot, although it was not elaborated there. What is even more interesting

169 For additional examples of the double Torah in Abulafia, see Idel, Language, Torah, and Hermeneutics, 73-81. See also Idel, Enchanted Chains, 144-51.

170 Maimonides had more than one view on this issue. See Benor, Worship of the Heart, 186-87, note 67; Dov Schwartz, "Psychological Dimensions of Moses's Prophecy-Imagination and Intellect" [Hebrew], in Moses the Man, 251-83; and Kreisel, “The Prophecy of Moses, 179-204.” For Abulafia on this point, see Hayyei ha-Nefeš, 157, and Sitrei Torah, 167.

171 See Pines, “Some Views Put Forward by the 14th-Century Jewish Philosopher Isaac Pulgar," and Schwartz, "On the Concepts of Prophecy of Rabbi Isaac Pulgar, Rabbi Shlomo Al-Qonstantini and Spinoza." 
is that it was not hinted at as a secret either. Only someone who sufficiently understands the Neo-Aristotelian intellectual apparatus and its problematic application to religion is capable of accurately guessing the Kabbalist's message. This means that the idea of the Torah as a median and thus as related-structurally, and, in my opinion, also conceptually - to the imaginative faculty had been present since Abulafia's pre-Kabbalistic philosophical period, stemming as it does from a type of thought which had a Muslim falāsifah background. However, he did interpret it during his "Kabbalistic" years later on by resorting to linguistic methods. ${ }^{172}$

It is, therefore, not that the gematria for Torah (emșa it, 611) generated the nexus between these two concepts; rather, it is a profoundly philosophical theory that has been strengthened by the discovery of this numerical affinity, just as happens with the connection between nature and Elohim; namely, Elohim (ha-teva', 86), a topic about which we shall have more to say below. ${ }^{173}$ However, in time, the original philosophical nexus became the starting point of linguistic speculations as, for example, in the following discussion in Abulafia's untitled treatise, where he writes, in quite a dense manner: "Behold, the Torah is median, a true tree, the spring of truth, a complete token, and be aware to understand the tree of life in the garden as the letters of the twenty-two ${ }^{174}$ in their perfect names, whose number is fifty-eight."175 Here, the term emșa'it (Torah) is interpreted according to gematria: "true tree” ('eș amitti), "spring of truth" (ma'ayan emet), and "a complete token" (mațbe'a tamim) all amount to 611. However, more interesting is the first phrase, "true tree” ('eș amitti), whose consonants are exactly those of emșa it when rearranged.

What is new here is the interpretation that takes the gnoseological discussion in the direction of linguistic speculations as to the names of the twenty-two letters of the Hebrew alphabet. Elsewhere in the same treatise, he writes:

The secret is so because of its being a point, a small ${ }^{176}$ letter, and we are called Yešurun ${ }^{177}$ because of the letter, and because of the point. And there can be no doubt that "point," Emșa it,

172 On the nexus between emșa iyyot ("the median ones") and imagination, see Rabbi Nathan ben Sa'adyah, Le Porte della Giustizia, 476.

173 Beside note 697.

174 Namely, the number of the letters of the spellings of the names of the twenty-two letters. See also Ms. Firenze, Laurenziana, Plut. II, 48, fol. 74b: אותיות הקדש הן עץ החיים זהו שם המיוחד.

175 Ms. Firenze, Laurenziana, Plut. II, 48, fol. 92b:

כי הנה תורה היא אמצעית עץ אמיתי מעין אמת מטבע תמים ושים לבך להבין עץ החיים בתוך הגן כי האותיות של כ"ב

בשמותם שלמים מספרם ח"ן.

See also Ms. Firenze, Laurenziana, Plut. II, 48, fol. 93b. For the identification of the Torah with the theosophical concept of the median line, קו אמצעית, in Hebrew, see Ms. Firenze, Laurenziana, Plut. II, 48, fol, $97 \mathrm{a}$.

176 In Hebrew, Qațan (“small”) is masculine, unlike $O t$, which is a feminine letter, because QaṬN amounts to 159 like $\mathrm{NeQuDaH}$ and 'OlaM Ha-BA' ("the world to come”). See also Commentary on Sefer Yeșirah, 24.

177 Cf. Deuteronomy 32:15. 
refers to [the fact that] the world to come [is] Torah, and likewise "the palace of holiness"178 is knowledge, "that is arranged in the middle," in the twenty-two letters, and in all the worlds. ${ }^{179}$

The small letter is Yod, which is, from the graphical point of view, a dot. That there is a secret here is obvious from the beginning of the passage. The only clue to the secret is found in the mention of knowledge being related to the palace. Here, the specifically philosophical terminology has been removed and the linguistic speculations have taken over. However, the meaning of those phrases did not remain solely on their literal level or take significance only if interpreted, but Abulafia hinted at the existence of a secret that will be revealed only with the coming of the Messiah. Here, however, the Torah as a median entity is related to the intellectual status of this entity, identical to the Agent Intellect, ${ }^{180}$ which differs from what we have seen in the earlier cases, where mediation was connected to the imaginative faculty.

Let me ponder upon some of the affinities hinted at in the above passages: the Torah is Emșa it, but it is also related to the twenty-two letters. It seems that we may learn something here about Abulafia's intentions that permeates some of his rather cryptic statements. In his Sitrei Torah, we find the following compact and rich statement:

[The letters of] Otiyyot ha-Qodeš amount in gematria to 1232, and afterwards calculate as you can so that it will amount to 1232, like, for example, Otiyyot ha-Qodeš is in gematria ha-Torah ha-Emșa it, and also ha-Torah is in gematria ha-Emșa it. And so also Otiyyot ha-Qodeš [amounts] in gematria to Limmud Mișwot ha-Torah. And also Limmud Mișwot [amounts] in gematria to Selem u-demut. Afterwards, skip the thousand and return it to one and say Otiyyot ha-Qodeš [amounts] in gematria to Be-rla, and its secret is G[o]r[a]l R[e]g[e]l and it is 'Es ha-Hayyim. ${ }^{181}$

178 On the "palace of holiness" and knowledge, see chapter 24 below. Abulafia's passage is influenced by Sefer Yeșirah, 4:3.

179 Ms. Firenze, Laurenziana, Plut. II, 48, fol. 92ab:

והסוד הוא מפני היותה נקדה אות קטן ועליה נקראו עמנו ישורון בסבת אות ובסבת נקדה ואין ספק כי נקודה אמצעית מורה לנו כי העולם הבא תורה וכן היכל קדש שהוא דעת מכון באמצע כעשרים ושתים אתיות וכן בכל העולות נולם. See also another discussion of the median point in Ms. Firenze, Laurenziana, Plut. II, 48, fol. 77a. 180 See Idel, Language, Torah, and Hermeneutics, 29-38. I wonder whether the two aspects of the Torah, the intellectual and the imaginary, fit the distinction between numen and nomos, respectively, in the Andalusian falāsifah as formulated by John Wansbrough, The Sectarian Milieu: Content and Composition of Islamic Salvation History (Oxford: Oxford University Press, 1978), 131, 135-36.

181 Sitrei Torah, 141:

אותיו"ת הקד"ש בגימטריא עולים תתתל"ב ואחר כן תעשה מהם חשבונות כפי יכלתך שיעלו אלף ומאתים ושלושים ושנים.

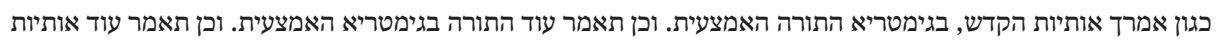

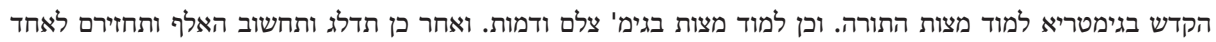

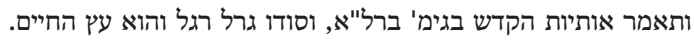
For a partial parallel to the end of the passage, see Mafteah ha-Hokhmot, in Wolfson, Abraham Abulafia, 213-14, and note 108. The gematrias are not deciphered in this text; the author reaches a different conclusion from the one I reach here. 
What is important here is the various calculations gravitating around the numerical values of the Otiyyot ha-Qodeš, the holy letters. On the one hand, it stands for the combined value of ha-Torah and ha-Emșa it, and on the other for Limmud Mișot ha-Torah. Let me elaborate on the last gematria: "the study of the Miswot of the Torah" is related to the holy letters, which I understand to mean that in Abulafia's opinion, it is not the performance of the commandments that is central, but rather their study, which is tantamount to the calculation of the numerical values of the combination of the letters that are used in the Hebrew Bible in order to articulate those commandments. The gematria is obvious: Limmud Mișot $=H a-T W R a H=$ 616 , which means that the study of the commandments constitutes the Torah.

Such an understanding, which probably prefers the study to the performance, may point to a Maimonidean view, as analysed by Warren Zev Harvey, concerning the superiority of the study of texts about sacrifices over the act of sacrifice. ${ }^{182}$ On the other hand, the combination of letters is hinted at by the consonants be-rla, whose numerical values amount to 233 . This is a figure that is conceived here as emerging from $1232=1+232=233$. The figure 233 represents "by means of the 231 combinations of letters" and also means, inter alia, 'Eș ha-Hayyim, the tree of life; it is also related to the 232 combinations of letters hinted at in Sefer Yeșirah.

The linguistic speculations are also related to more traditional terms such as Selem $u$-demut $=616=$ ha-Torah $=$ ha-Emșa it. Following Maimonides, image and likeness mean intellect and imagination in Abulafia's thought. I will summarise the above passage in a manner that also contributes to the other passages quoted in this chapter: the study of the letters of the Torah or of the commandments is conducive to an intellectual experience that also includes imagination; namely, a prophetic one that also has eschatological overtones, as the mention of the tree of life shows.

Let us turn to another interpretation of the gematria Torah =Emșa it, found in an unidentified passage preserved in several manuscripts. It is part of a more magical approach that deserves a detailed discussion that cannot be undertaken here:

This is the reason that man was given permission to change natures by dint of the power of the knowledge of the [divine] name vocalised, ${ }^{183}$ and the secret of its vocalisation is written in the Torah, ${ }^{184}$ Ševa', Holam, Qamaș, whose numerical value is Torah, and it is Emșa $i t,{ }^{185}$ of the supernal and the inferior [worlds]. And I shall tell you why man can change nature: you should know in truth that God, blessed be He, created His world by the power of his special name and He gave it to the First Man [Adam ha-Rišon], who is known [as] the secret Adam 'Elyon, ${ }^{186}$ in order to rule

182 See his interesting “Les sacrifices, la prière et l'étude chez Maïmonide," REJ 154 (1995): 97-103. See also chapter 8 note 15 above and Appendix E note 16 below.

183 See Mafteah ha-Sefirot, 68.

184 For the vocalisation of the divine name with these three vowels, see Oșar 'Eden Ganuz, 3:8, 341, and Idel, "Ashkenazi Esotericism and Kabbalah in Barcelona," 99.

185 Torah = Emșa it = Ševa', H[o]lam, Qamaṣ = 611. See also Joseph Gikatilla's Ginnat Egoz, 98. 186 This is most likely the Agent Intellect or Metatron, who has been described in some cases as the supernal man. See Sitrei Torah, 70, and Idel, Studies in Ecstatic Kabbalah, 82. 
over the world by its means. And just like He gave it to the Last Man, who is known, and He gave to both of them power to rule over the world, one [governs] the supernal [world], the other the inferior [world]. ${ }^{187}$

The vocalisation of the Tetragrammaton by the three vowels, two of them also found in the Hebrew form of the Torah, is conceived as the highest way of manipulating the created world, just as the Agent Intellect or Metatron does so in the supernal world. The "last man" may stand for the Messiah, following the Pauline description of Jesus. ${ }^{188}$ Indeed, Abulafia describes the Messiah elsewhere as using divine names in a manner perhaps relevant for the way he envisioned himself: "And then there will be the true ${ }^{189}$ time of the Torah. When? When the Messiah of $Y H W H$ will rule over the entire Merkavah, [so as] to change natures in accordance with the will of God."190

However, the Pauline source mentioned above has been allegorised by assuming that it is the First Man-namely, a metaphysical structure and not the first historical man conceived as a sinner-who is found on high, not the last one, who is envisioned as active here below. Though maintaining the Pauline vision of the last man as the Messiah-namely, as Jesus-Abulafia substitutes the latter for himself, as he is the true Messiah who uses the divine names.

Polemical or not, the structure of this passage tells a story that is different from the Christian source, since here it is the Torah that remains active, though magically as related to the Tetragrammaton and not ritualistically in the present. To put the

187 Ms. New York, JTS 1887, fol. 119a, Ms. Budapest, Kaufmann 238, 129:

ולפיכך נתן לאדם רשות לשנות הטבעי' בכח ידיע' הש' בניקודו, וסוד נקודו הכתו' בתורה שב"א חל"ם קמ"ץ במניינם תורה

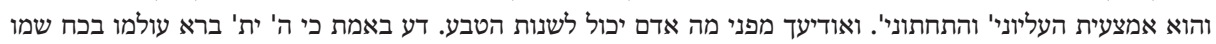

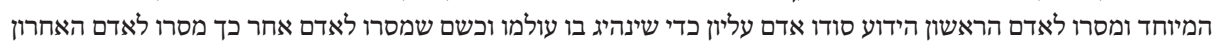

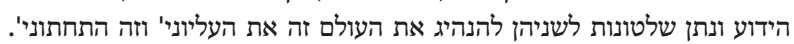
In my opinion, this anonymous text is part of the material stemming from Abulafia's school.

188 Cf. 1 Corinthians 15:45-49: "The first man Adam became a living being; the last Adam, a life-giving spirit. The spiritual did not come first, but the natural, and after that the spiritual. The first man was of the dust of the earth, the second man from heaven. As was the earthly man, so are those who are of the earth; and as is the man from heaven, so also are those who are of heaven. And just as we have borne the likeness of the earthly man, so shall we bear the likeness of the man from heaven." See also below in Abulafia's passage referenced below in chapter 17 note 140; see also chapter 17 note 136.

189 Compare also to the true performance of the commandments mentioned above in the same book.

190 Untitled Treatise, Ms. Firenze, Laurenziana, Plut. II, 48, fol. 89a:

ואז יהיה זמן תורה, אמתי? כשישלוט משיח יהו"ה בכל המרכבה לשנות הטבעים כרצון השם.

On the divine names as the tools of the Messiah, see Ms. Firenze, Laurenziana, Plut. II, 48, fol. 90b. I assume that the "true time of the Torah" is a hidden polemic against the famous Rabbinic view on the six thousand years, two of Tohu, two of Torah, and two of the Messiah. For more on this passage, see note 720 below. As Prof. Menachem Kellner pointed out to me, this passage should be understood in the context of Nahmanides's similar term. See his commentaries on Genesis 37:2, Numbers 15:22, and Deuteronomy 30:6. 
passage from the anonymous text into the context of the discussion from the Untitled Treatise presented earlier: here, we have a more messianic interpretation that is combined with magic, while earlier we saw a more spiritualistic approach, dealing as it does with the experience of the world to come by the individual who redeems himself.

Thus, while collecting the various uses of the gematria Torah = Emșa'it, we may find some form of consistency as well as developments moving from a more philosophical interpretation of the median position as imagination to a form of gnosis conceived as linguistic, magical, or eschatological. In the context of the quote from the Untitled Treatise, Abulafia is speaking, in my opinion, about the angel of the covenant, mal'akh ha-Berit, who is found in the middle of some form of revelation that is taking place in the allegorical paradise, which is tantamount to manipulation of the linguistic material. Thus, I assume that it is the Agent Intellect, ${ }^{191}$ who is traditionally referred to as Metatron, the angel of the Torah, the angel of the face or presence, and, rarely, the "angel of paradise" who stands behind the angel of the covenant. It is described as an emissary-perhaps the imagination-of the Agent Intellect, related to redemption, and the divine name, most probably related to Elijah, who was described as the angel of the covenant and as including the divine name. ${ }^{192}$ In order to resort to a view found in many cases in Abulafia's writings as well as in the Untitled Treatise, what was received by tradition, qabbalah-in a written, oral, or revealed manner-should be confirmed by means of the intellect that can validate the "hidden secret," ${ }^{193}$ a view quite different from Nahmanides and his followers' perception of Kabbalah.

The imaginative status of the Torah according to these statements may also have something to do with Abulafia's assumption that unlike the study of their letters, the commandments themselves are related to imagination, a view implied in the above passage from Or ha-Sekhel as well as elsewhere in the same book. ${ }^{194}$ In any case, in what I consider to be a seminal discussion, Abulafia distinguishes between the knowledge of the divine name of the distinguished individual, ${ }^{195}$ who is portrayed as an extraordinarily rare person, on the one hand and the Torah, commandments,

191 The philosophical term is mentioned in the Untitled Treatise in Ms. Firenze, Laurenziana, Plut. II, 48, fols. 69a, 76a, 79a, 95a. For Metatron as Agent Intellect among the Maimonideans, see The Writings of Rabbi Moses ibn Tibbon: Sefer Pe'ah, 99, 102, and Albalag, Tiqqun ha-De'ot, 58, 60.

192 See Ms. Firenze, Laurenziana, Plut. II, 48, fols. 69a, 71b, 89b-90a. For a special concern with Paradisiacal imagery, see the Abulafian-oriented Sefer Or ha-Menorah, Ms. Jerusalem, NLI $28^{\circ} 1303$, fols. 26b-27a.

193 Ms. Firenze, Laurenziana, Plut. II, 48, fol. 71a: יתאמת לך הסוד הנסתר הזה שכן הוא גם מצד השכל אחר הקבלה.

194 See the texts discussed in my "The Battle of the Urges: Psychomachia in the Prophetic Kabbalah of Abraham Abulafia," 124-34, especially 132, note 151; the text from Oṣar 'Eden Ganuz, 1:2, 90; and Mafteah ha-Tokhahot, 122-23. I hope to return to this theme in more detail elsewhere.

195 See Mafteaḥ ha-Šemot, 39. 
and good deeds that are conceived as the "gatekeepers"196 on the other. These values were used instead of the knowledge of the name since they "are sufficient for the multitude to worship the gatekeepers and these are only for the best of them."197 The phrase "worship of gatekeepers" is quite an exceptional expression in medieval Judaism, even more so when they are identified with the Torah and commandments. Earlier in the same book, Abulafia speaks about the gatekeepers at the gates of wisdom; namely, philosophers. ${ }^{198}$

The linkage between the Torah and the multitude is reminiscent of that between the Torah and the imagination on the one hand and between the commandments and the imagination on the other. If we identify the so-called "distinguished individual" as someone who is undergoing some form of intellectual training or experience that is related to the divine name, as we shall see in some detail in chapter 21 below, he is distinguished, namely separated from the strong imaginative inclination of the multitude. In this context, the view of an anonymous Kabbalist from Abulafia's school should be mentioned: he speaks about the parables as the melis (the intermediator, the emșa $i$ ) between the intellectual and sensual interpretations of the Torah. ${ }^{199}$ However, this Kabbalist was much more conservative than Abulafia and does not resort to the category of imagination in the context of his discussion of the Torah's content. ${ }^{200}$

The assumption that there is an important secret related to the Torah is found in Abulafia's commentary on Exodus, where he writes that he will not mention anything related to the revelation of the Torah at Sinai there since this is not a topic that should be written in a book, but it should rather be received "from mouth to mouth." ${ }^{201}$ This is quite a revealing formulation, even if the Kabbalist does not expli-

196 The gatekeepers were originally those who opened the gates of the Temple during the day, though here they may refer to astronomical entities or the angels that are mentioned in the Hekhalot literature.

197 Oșar 'Eden Ganuz, 3:9, 354-55:

וכשימצא איש מיוחד מתפאר בה יכחישוה השומעים מפני שלא נתפרסמה להמון כאשר היא. אבל הושמו במקומה שועריה

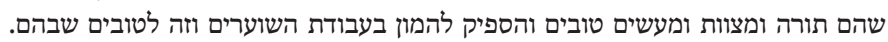

On the Torah and commandments as guiding people to the gates of the palaces, see Oșar 'Eden Ganuz, 1:3, 130. On the "distinguished man," see the discussion in chapter 21 below.

198 Oșar 'Eden Ganuz, 3:7, 330.

199 Sefer ha-Șeruf, ed. Gross (Jerusalem: 2004), 24-25.

200 In my opinion, this book, extant in two versions, only one of which has been printed, was not written by Abulafia. See my analysis in “Abraham Abulafia's Works and Doctrine," 69-72. However, without referring to my arguments at all, Sagerman claims that it is Abulafia's (The Serpent Kills, 56, note 91 [where he translates the title in quite a surprising manner as The Book of Refinement instead of The Book of Permutation or The Book of Combination], 94, note 180; 205, note 84). Even the traditional editor of this book, Gross, viewed it as Abulafia's work. Let me remark that I am not correcting the mistranslations of Abulafia's texts in English scholarship if they do not affect the points I am trying to make in my study.

201 Mafteah ha-Šemot, 164: לא נזכיר דבר בעניין מתן תורה פה, כי אינו דבר שיכתב בספר אך דרכו היא לקבל עניין 
cate his opinion as to the meaning of the revelation of the Torah. It shows that it constitutes a supreme secret, and my assumption is that it has much to do with the issues we discussed earlier in this chapter as to the nature of the Torah. In any case, according to one of Abulafia's earlier books, the Israelites' journey in the desert to receive the Torah is interpreted as an allegory for the transition from the brain to the heart; that is, it is interpreted as a cognitive event of an individual and allegorised in some cases as the sun and moon. ${ }^{202}$

In short, Abulafia's discussions above should be seen within the framework of the Neo-Aristotelian intellectual apparatus; the secrets he hides fit the parameters of this apparatus. They are understood as implied in the inner structure of the biblical text. Moreover, as we shall see in chapter 22 below, Abulafia is one of the rare Kabbalists who spoke about a "new Torah," writing books entitled Berit Hadašah, "The New Covenant," and Sefer ha-Yašar. He claimed that his prophetic books should be read in synagogues along with those of the biblical prophets. Such facts imply an innovative-not to say subversive-attitude towards the Jewish canonical writings as they were understood in traditional Jewish circles, and an at least implicit attempt to supply an alternative to them, as some of the titles of Abulafia's prophetic books show, Sefer ha-Haftarah, to be read in the synagogues on the Sabbath, like the books of the biblical prophets, or Sefer ha-Berit. It assumes some form of apostolic consciousness that attempts to coagulate itself in scriptural articulations that are highly esoteric in style. 